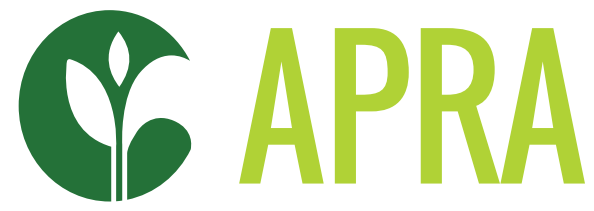

Agricultural Policy Research in Africa

\title{
COVID-19 AND THE POLITICAL ECONOMY OF TOBACCO AND MAIZE COMMODITY CIRCUITS: MAKORONYERA, THE 'CONNECTED' AND AGRARIAN ACCUMULATION IN ZIMBABWE
}

Toendepi Shonhe 


\section{CONTENTS}

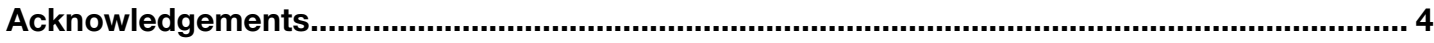

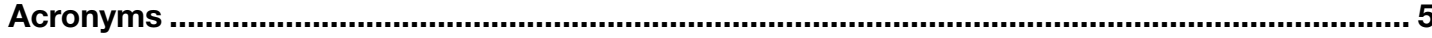

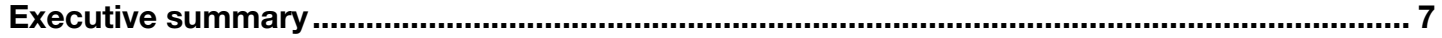

1. Introduction

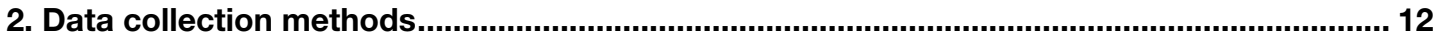

3. Mapping maize and tobacco commodity circuits .......................................................... 13

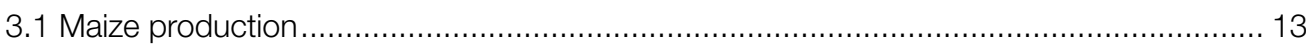

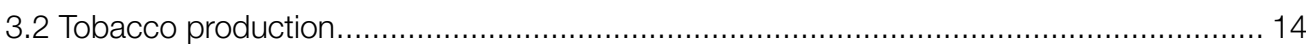

4. Commodity circulation: from Mvurwi to the global markets.................................................. 17

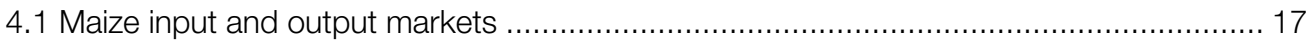

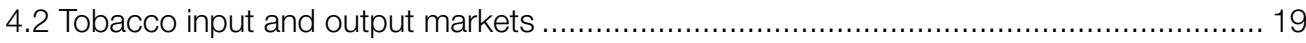

5. Changing commodity markets under COVID-19 .................................................................. 22

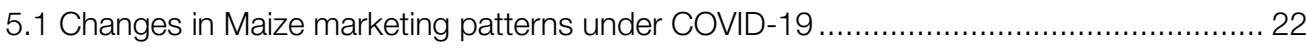

5.2 Changes in tobacco marketing patterns under COVID-19 ….................................... 22

5.3 The supply of productive assets under COVID-19 ................................................. 24

6. Politics and social differentiation: who wins and loses? ........................................................ 25

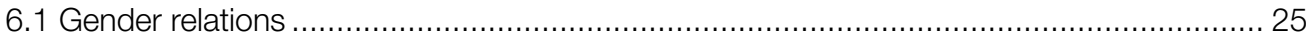

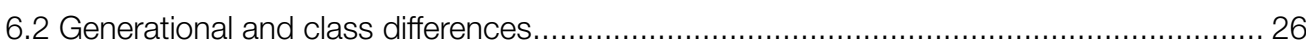

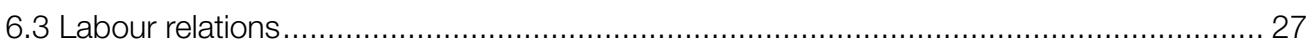

6.4 Entangled accumulation, political settlement, and social difference .............................. 27

6.5 Collapsing state regulations and the militarisation of agricultural financing ..................... 28

6.6 Entangled accumulation and the social relations of production ..................................... 28

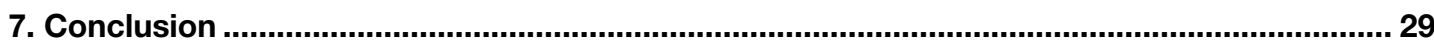

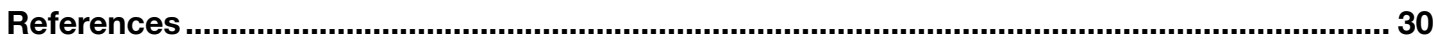

Appendix

Figures

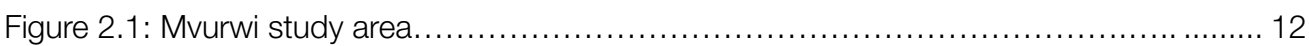

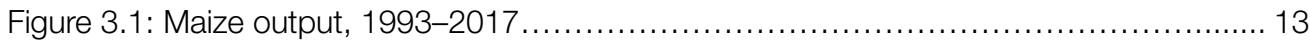

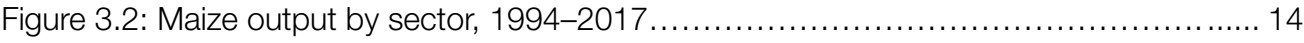

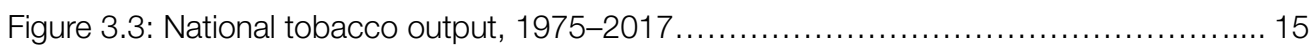

Figure 3.4: Sectional tobacco output per sector, 1993-2017 .............................. 15

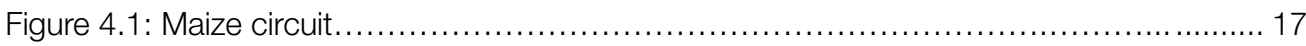

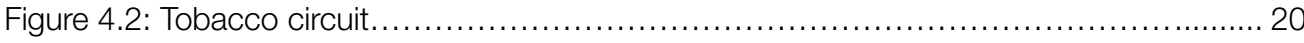

Figure 6.1: Financing options for youth in Mvurwi area for 2016/17 season...................... 27 
Tables

Table 3.1: Week 53 mass deliveries by contract and non-contract farmers per

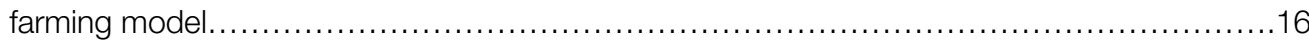

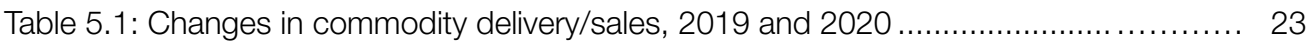

Table 5.2: Changes in agro-trading under COVID-19 ........................................ 24

Table 6.1: The percentage of women farmers accessing financing and marketing through

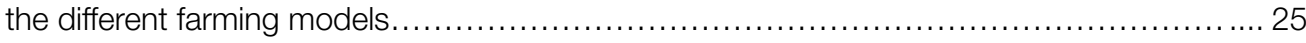

Table 6.2: Crop production by gender per farming model..................................... 26

Table 6.3: Average asset ownership by gender per farming model.......................... 26

Table A1 Population densities in oil palm growing areas ......................................... 36 


\section{ACKNOWLEDGEMENTS}

This study was carried out with funding provided by the Agricultural Policy Research in Africa (APRA) consortium. APRA is a five-year research programme that works across three work streams investigating pathways to agricultural commercialisation in six focal countries, including Zimbabwe. APRA is funded by the UK Foreign Commonwealth and Development Office, formerly the Department for International Development. The author would like to acknowledge the key role of research assistance in this study, particularly assistance in data collection by Terrence Chimhavi, Simbai Mutimbanyoka, and Tsitsidzashe Bvute. The author would also like to thank Mr Athanas Chimombe, a Senior Agritex Officer in the Agritex Department, Ministry of Agriculture, for his assistance during fieldwork and data collection.

Toendepi Shonhe is a political economist and researcher at the Thabo Mbeki African School of Public and International Affairs, University of South Africa.

This working paper is funded with UK aid from the UK government (Foreign, Commonwealth \& Development Office - FCDO, formerly DFID). The opinions are the authors and do not necessarily reflect the views or policies of IDS or the UK government. 


\section{ACRONYMS}

A1

A2

APRA

BAT

BTF

CA

CASA

CNTC

FGD

FTLRP

GCC

GMAZ

GMB

GNU

GVC

$\mathrm{HCl}$

IFPRI

KII

LSCF

MTC

NT

ORA

RBZ small-scale farmers settled under Zimbabwe's Fast Track Land Reform

middle-scale farmers settled under Zimbabwe's Fast Track Land Reform

Agricultural Policy Research in Africa

British American Tobacco

Boka Tobacco Floors

communal area

Commercial Agriculture for Smallholders and Agribusiness

China National Tobacco Corporation

focus group discussion

Fast Track Land Reform Programme

global commodity circuit

Grain Millers Association of Zimbabwe

Grain Marketing Board

Government of National Unity

global value chain

Household Commercialisation Index

International Food Policy Research Institute

key informant interview

large-scale commercial farm

Mashonaland Tobacco Company

Northern Tobacco

old resettlement area

Reserve Bank of Zimbabwe 
SHF

SSCF

TIMB

TRB

TSF

TZTC

ZANU PF

ZFC Z smallholder farmer

small-scale commercial farmer

Tobacco Industry Marketing Board

Tobacco Research Board

Tobacco Sales Floor

Tian Ze Tobacco Company

Zimbabwe African National Union - Patriotic Front

Zimbabwe Fertilizer Company Pvt Ltd 
This paper analyses the global commodity circuits (GCCs) - value chains - for maize and tobacco in Zimbabwe, in the context of a reconfigured agrarian economy and COVID-19 induced shocks. The study focuses on the political economy dynamics of agricultural commodity circuits to reveal how they can contribute to understanding the drivers and constraints of agricultural commercialisation in Zimbabwe. The study was carried out in Mvurwi, a farming area in Mazowe district in Mashonaland Central Province, about $100 \mathrm{~km}$ north-west of Harare. This paper traces the circuits of maize and tobacco, the two major crops for food security and foreign currency earnings in Zimbabwe. Maize is the staple food, while tobacco contributes to about 24 per cent of foreign currency earnings and 4 per cent of gross domestic product. However, COVID-19 induced regulations are likely to trigger increased illicit trade, corruption including fraud, theft, and pillaging along agricultural commodity circuits. This will likely impact on agricultural commercialisation and who wins and loses along the GCC.

Commodity circuit analysis provides insights into how shifting land ownership and production patterns, financing, and marketing affects the periphery differentially across the various scales of farming. Measures adopted to contain COVID-19 have disrupted existing commodity circuits and generated changes in the actors and their interests in commodity circuits, which has fashioned new trajectories of social differentiation (The Economist 2020). While vaccines have now been developed, the impact of the initial lockdown on agricultural technological innovation and other management aspects are expected to have longlasting implications for commodity circuits, long after the pandemic is over (ibid). Along the domestic commodity circuits, the informal sector has been significantly affected, as health hygiene restrictions were imposed at the aggregation centres and warehouses, impacting on their businesses. While there has been minimal disruption in farm-level operations, logistical disruptions have resulted in food shortages and price increases. In the context of COVID-19, participation in commodity circuits may lead to the accumulation of wealth for some and sliding into poverty for others, predominantly with small-scale farmers being the losers.
While tobacco is mainly extroverted (externally oriented) and maize is introverted (internally oriented), through exports and domestic supply, respectively, surplus value extraction undermines farmers' capital accumulation prospects. Smallholders have been the most affected by the COVID-19 induced disruptions as they now dominate in the production of both commodities, following the land reform in 2000. Tobacco is predominantly grown under contract farming, with 94 per cent of communal area (CA) farmers and 99 per cent of resettled farmers growing tobacco under this arrangement. The Tobacco Industry Marketing Board's (TIMB) records reveal that at least 52.1 per cent of this tobacco is sold through aggregators (makoronyera). However, the data collected from the farms show that formal contract sales were far lower in 2020 , at 30.3 per cent of total sales. This reflects the high prevalence of illicit trading, which begins with makoronyera at the farms through to the auction floors and illicit exports that are led by well-connected individuals. Illicit tobacco trade is most prevalent between Zimbabwe, as the biggest tobacco producer in Africa and its neighbouring countries, with South Africa being the most significant market. Similarly, for maize, 65.8 per cent is sold through aggregators and traders/makoronyera, while 32.1 per cent is delivered to the Grain Marketing Board (GMB). The informal markets also start at the farm gate and end up in informal markets in Harare and other towns. Some informally sold maize may also shift into the formal channels, as makoronyera consider options for commodity markets. The politics of the maize commodity circuit begins at primary production, continuing all the way to processing. It is linked to financing for primary production and processing. Equally, who gets to import and distribute or secure the commodity for milling and eventually for retail trading is a political outcome.

The reconfiguration of commodity circuits due to COVID-19 induced disruptions of the transport system and other logistics systems, including the closure of aggregation centres and warehouses, has affected market access. Access to seeds and other imported inputs was made more difficult by the need for foreign currency, in a context where the trade of farm commodities is in local Zimbabwean dollars. 
Farmers considered this trade matrix unviable, due to the ballooning foreign exchange rate. Some farmers suggest the decentralisation of the marketing system in which tobacco auction floors were established in other towns besides Harare, made it difficult for makoronyera in Harare to collude with buyers to manipulate the prices. The opposite applies for maize, where higher deliveries by vulnerable growers facing cash shortages under the weight of COVID-19, were being forced to sell at far lower prices and to fewer local makoronyera. While the GMB has introduced an early maize delivery incentive and relaxed moisture content requirements, prices have remained low and unfavourable to farmers.

The GCCs are politically mediated. In the maize circuits, access to Command Agriculture is mediated by 'a coalition of political actors' within the ruling party in government and within the military, who distribute rents to preferred groups of farmers. The tobacco circuits promote direct linkages between international contractors and growers of different scales. This limits the role of the state and patronage. However, the rise of makoronyera in the marketing process and, ultimately, the illicit export of tobacco connected to 'a coalition of political actors', undermine the growers and promote illicit capital accumulation by a few 'untouchables'.

Under the weight of patriarchal practices, and more recently, the COVID-19 pandemic, women remain excluded from state sponsored farmer support programmes, such as Command Agriculture. However, the youth are faring well compared to other age groups.

In comparison to farmers and farm workers who lack voices, processing associations are politically connected and control both the formal and informal markets, including illicit makoronyera trading, across borders and at the retail level. Makoronyera thrive in an environment where the rule of law is in doubt and law enforcement mechanisms are weak. In this sense, the need for government to ensure the eradication of impunity and provide an enabling macro-economic environment for sustainable commodity circuits cannot be over-emphasised. 
This paper analyses the global commodity circuits (GCCs) for maize and tobacco in the context of a reconfigured agrarian economy and COVID-19 induced shocks in Zimbabwe. Commodity circuit analysis provides insights into how shifting land ownership and crop production patterns, financing, and marketing affect the periphery differentially across the various scales of farming. Unlike traditional methods of economic and social enquiry, value chain analysis' focus on the inter-linkages within the productive sector and the global interaction of countries, firms, and individuals, provides a broader and more nuanced analysis. Such an analysis can reveal who wins and who loses in the production and distribution of commodities and services (Gereffi and Fernandez-Stark 2011).

Measures adopted to contain COVID-19 in 2020 disrupted existing commodity circuits, which generated changes in the actors and their interests in commodity circuits, fashioning new trajectories of social differentiation (The Economist 2020). While vaccines have now been developed, the impact of the initial lockdown on agricultural technological innovation and other management aspects are expected to have long-lasting implications for commodity circuits long after the pandemic is over (ibid). The informal sector has been affected as health hygiene restrictions imposed at aggregation centres and warehouses constrained the movement of producers and goods. While there has been minimal disruption to farm-level operations, logistical disruptions curtailed the transportation of commodities from the farms, resulting in food shortages and price increases. It is hypothesised that these challenges and risks sustain entangled accumulation (Gonçalves and Costa 2020) in which surplus value extraction is sustained and reconfigure political power dynamics along the commodity circuits, impacting on agricultural commercialisation in Zimbabwe.

As Poulton and Chinsinga (2018) argue, national policies may affect land tenure in ways that may impact production patterns and commodity value chains. While reversing the skewed land ownership patterns from
2000, Zimbabwe's dramatic Fast Track Land Reform Programme (FTLRP) also broadened smallholder farmers' (SHFs) participation in commodity production. Since the early 1980s, the land reform programmes have transferred 10 million ha (Moyo 2011) and added 140,000 households to an existing total of 1.7 million smallholder producers in the communal and old resettlement areas (Binswanger-Mkhize and Moyo 2012). The new tri-modal agrarian structure introduced after 2000 includes 8,000 small-scale commercial farmers (SSCFs) and about 300 remaining large-scale commercial farms (LSCFs). Besides altering landholding patterns, the emergent land tenure comprises less than 10,000 farms owned by the SSCF, LSCF, and indigenous commercial farmers under the private freehold tenure. This is down from 15,000 in 2000 . Additionally, over 25,000 plots are now held under long-term leases, up from 3,000 in 2000. The number of households owning land under land grants and permits expanded from 100,000 in 2000 to 215,000 by 2012 . There has also been a simultaneous shift among tobacco producers from LSCFs to SHFs. The SHFs' share of total maize production increased from 53.6 per cent in 1980 to 72.6 per cent by 2011, and to 74.1 per cent by 2017. Similarly, SHF's contribution to tobacco production rose from below 15 per cent in 1980 to 40 per cent in 2011 and 68.1 per cent in 2017 (MLAWCRR 2017).

This land reform process also coincided with the imposition of sanctions by European Union and the US, which triggered capital flight (Moyo and Nyoni 2013; Scoones et al. 2010), resulting in foreign currency shortages and the disruption of farm input commodity circuits, while altering the demand and scale of operations along the circuits. The sanctions also caused the closure of European markets for horticultural and beef produce and altered tobacco and maize commodity circuits. Although Zimbabwe produces 16 agricultural commodities, including beef and dairy products (Binswanger-Mkhize and Moyo 2012), maize and tobacco are the major crops for food security and foreign currency earnings. Maize is the staple food in Zimbabwe and tobacco contributes to about 24 per

1 Moyo (2011) proposed the emergence of a tri-modal agrarian structure in which the peasantry (A1 farmers and CA farmers), middle-scale farmers (A2 farmers and SSCFs), and the remaining agro-estates dominate, following the Fast Track Land Reform Programme (FTLRP) of 2000. 
cent of foreign currency earnings, as well as 4 per cent of the gross domestic product (TIMB 2015).

The GCCs are also known as global value chains (GVCs) and were defined by Gereffi, Humphrey, and Sturgeon (2005) as the globally dispersed networks of firms and other institutional actors that coordinate to produce given goods or services for consumption. The GCC is the neoclassical version of the former, however, they both originate from the world systems approach introduced by Wallerstein (1974). This theory, which traces the development of the modern world, emphasises the social structure of global inequality that holds up the skewed commodity trade. The paper adopts a radical political economy approach (Cousins and Scoones 2010) to examine the dialectic of production and the circulation of historical materialism (De Janvry 1981), and understand how the land reform and the COVID-19 pandemic impact on the national economy. The paper analyses how exploitative structures that undermine smallholders' agrarian accumulation are shaping who wins and loses within the value chain. The use of GCCs rather than GVCs - a rather liberal term - fits the approach.

Tobacco is an extroverted (externally oriented) crop with geographically dispersed production and processing (Goger, Bamber and Gareffi 2014). Zimbabwe exports over 97 per cent of its tobacco as semi-processed to various destinations for further processing and the manufacturing of cigarettes and other tobacco products. Since 2000, Zimbabwe has barely produced sufficient quantities of maize to meet local demand and has often had to import maize from various countries. Thus, maize is an introverted crop (internally oriented), mostly consumed locally. Along these global and domestic commodity circuits, SHFs have immensely suffered from surplus labour extraction, the exportation of surplus value, and the loss of employment opportunities, as they are situated in the low value segments of the GCCs. Shifts in production and circulation of the two commodities were also observed at the financing level. For instance, the rise in contract farming and the introduction of Command Agriculture $^{2}$ impacted the marketing channels for tobacco and maize, respectively (Shonhe and Mtapuri 2020; Mazwi et al. 2019; Scoones et al. 2018). The changes in commodity circuits bear political significance in the intra-party politics of the Zimbabwe African National Union - Patriotic Front (ZANU PF) and inter-party politics, as they have an influence on who wins and losses in accumulation (Scoones 2015) and political power (Shonhe and Scoones, unpublished; Shonhe and Mtapuri 2020).

How then have power structures and actors' interests along the commodity circuits changed over time? How has politics affected participation in the commodity circuits? How has commercialisation or changes in its pathways influenced different outcomes and impacts for different groups in the long term? What changes have resulted within the context of the emergence of COVID-19? The FTLRP resulted in social differentiation based on new land ownership patterns (Moyo 2011). The adverse incorporation of farmers in GCCs results in primitive accumulation, where surplus value is extracted and exported to developed countries through mispricing, interest, and profits (Shonhe 2018; Shonhe 2020). This further entrenches social differentiation (Scoones et al. 2018) and class formation (Shonhe and Mtapuri 2020).

Following Wallerstein's (1974) world systems theory, Luxemburg (2015 [1913], 432) argues that through primitive accumulation, the internal circuit receives limited surplus value. For Fontes (2017), as Gonçalves and Costa $(2020,155)$ cite, the 'expansion of capitalism never occurred in the form of a fully normalized accumulation, but rather was always grounded in speculation, pillage, fraud and blatant theft'. This expropriation may be supported through political regulatory interventions (Gonçalves and Costa 2020), such as the restrictions on movement imposed under the COVID-19 pandemic. This disarticulation of the primary and secondary processes of production and circulation leads to what Gonçalves and Costa (2020) describe as entangled accumulation. It is argued therefore that entangled accumulation is ongoing and continuous.

In this sense, the COVID-19 pandemic, which triggered the imposition of regulations (IFPRI 2020), has the scope to result in the 'rapid disarticulation of the production, processing, distribution, and consumption of food', disrupting global food systems and further exposing the weaknesses of the commodity circuits (van der Ploeg 2020, 1-2). State lockdown regulations deactivate the economy (van der Ploeg 2020) and trigger shortages and shifts in supply chains, which impact surplus value extraction. Arguably, COVID-19 induced regulations are likely to trigger illicit trade, corruption, including fraud, theft, and pillaging, perpetuating entangled accumulation. It is conceivable that GCCs are being manipulated to meet political settlements, or

2 Command Agriculture is a government mediated contract farming system for food crops, such as maize, soya beans, and sugar beans. It is run through funding channelled by the government to the Central Bank of Zimbabwe, Stanbic Bank and Agribank. A stop order system administered by the GMB provides the mechanism to recoup the costs of seed, fertilisers, chemicals, tillage, and labour advanced to farmers under the scheme. 
that variations in geographical factors may influence the circulation of commodities at the domestic or global scale (Poulton and Chinsinga 2018). Within this contestation, participation in commodity circuits may lead to the deepening of entangled accumulation, where some will win, while others slide into poverty, mainly the small-scale farmers.

With farmers involved in GCCs that are skewed in favour of the importing countries in the centre, tendencies for social differentiation are conceivable. This calls for an examination of the 'complexity of interactions of multiple forms of social categories, including gender, age, class, religion, sexuality and ethnicity, in shaping social structures and matrices of inequality and oppression' as intersectionality theorists argue (Dancer and Hossain 2018). The use of a political economy lens, as adopted in this paper, allows for an analysis of the interplay of social structures, the patriarchy, and global capitalism (ibid).

This paper uses documentary analysis of secondary data sources, including official statistics from government departments, key informant interviews (KIls), and focus group discussions (FGDs). Following this introduction, section 2 discusses the methods and data analysis, while the next section (3) maps out the evolution of the maize and tobacco commodity circuits, assessing their changes over time. The structure of commodity circuits is presented in section 4. COVID-19 instigated changes in commodity marketing patterns in Mvurwi are discussed in section 5. In section 6, social differentiation emanating from policy contestation and the politics of commodity circuits are introduced, followed by a discussion in section 7. A conclusion is offered in section 8. 


\section{DATA COLLECTION METHODS}

The study was carried out in Mvurwi, a farming area in Mazowe district, in Mashonaland Central Province, about $100 \mathrm{~km}$ north-west of Harare, as shown in Figure 2.1. It is situated in the high potential agroecological region that receives an average of $800 \mathrm{~mm}$ of rainfall annually.

The FTLRP resulted in the resettlement of 4,529 A1 (small-scale) farmers and 319 A2 (middle-scale) farmers, who added to the pre-existing 2,709 CA households in Mvurwi, creating a tri-modal agrarian structure. Twelve Klls were administered in Harare at the tobacco auction floors, with directors of processing companies, and with directors in government departments in Harare. These included informants from TIMB, the Grain Marketing Board (GMB), food processing companies, tobacco processing companies, bankers, agricultural researchers and extension officers, tobacco merchants, agricultural input suppliers, and cigarette manufacturers. A total of six FGDs were also administered, two in each of the land-use areas (A2, A1, and CA). Document analysis of data secured from the Ministry of Agriculture, the Food and Agriculture Organization's database, Zimstats annual survey reports, a report from the GMB, the Department of Agriculture Extension Services in Mvurwi, and Concession town was carried out to triangulate the data.

Figure 2.1: Mvurwi study area

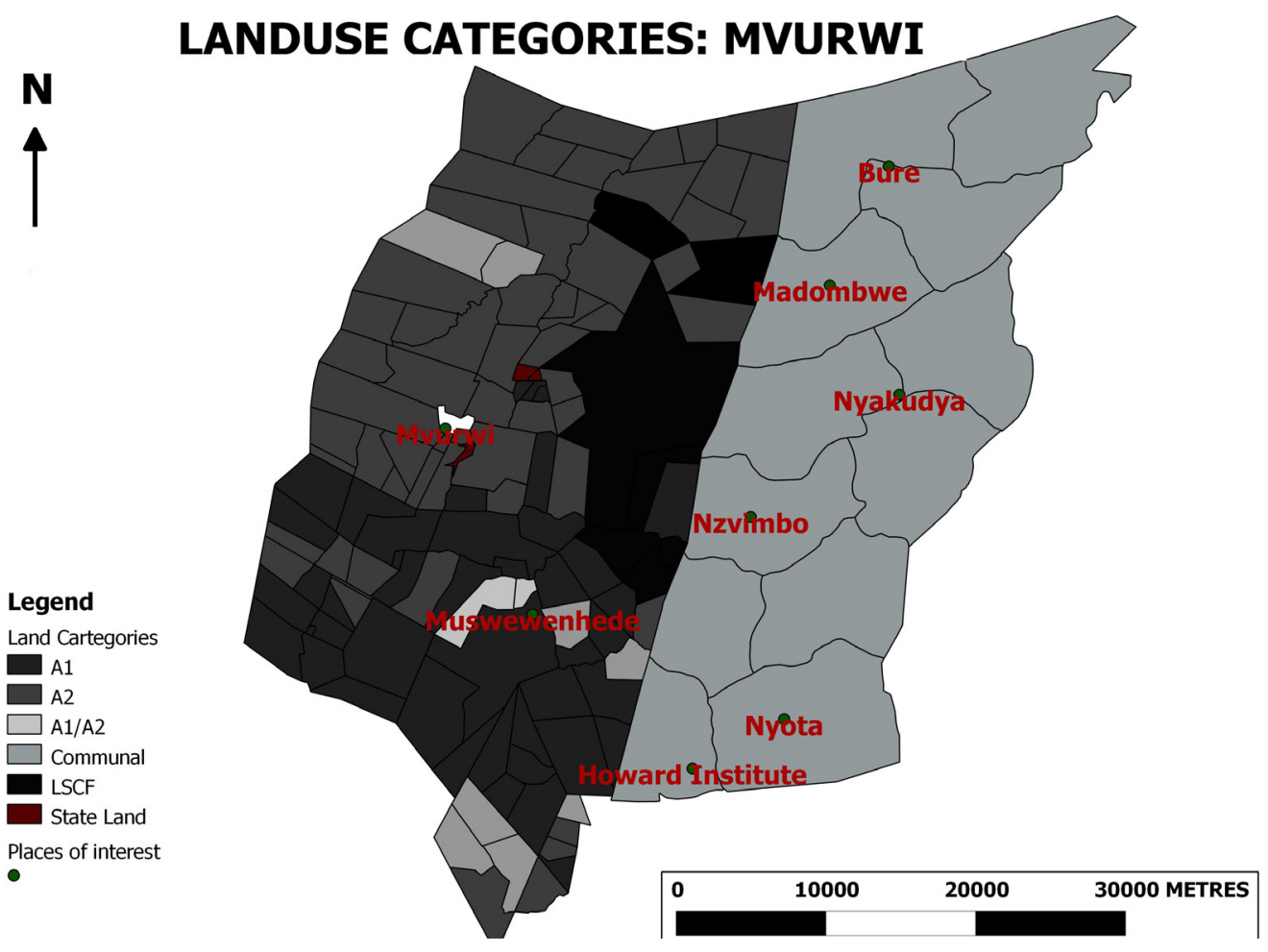




\section{MAPPING MAIZE AND TOBACCO COMMODITY CIRCUITS}

This section maps out the changing commodity production for maize and tobacco over time. In the main, these changes were associated and driven by the radical FTLRP and the changing financing and marketing options after 2000. These changes were also stirred by changes in the broader economy and geopolitics, especially in the case of tobacco. While the maize circuit is mostly introvert, serving the domestic market, the tobacco circuit is global and therefore extrovert. The government of Zimbabwe traditionally works with the TIMB and GMB in formulating tobacco and maize farming and marketing policies. These policies include the Tobacco Marketing and Levy Act (Chapter 18.20) (Chitongo 2017; TRB 2017) and the Grain Marketing Act (1957), through which the GMB is administered. This section discusses the production and circulation of the crops in the context of changing actors and policies, mainly after 2000.

\subsection{Maize production}

After four decades of land reform, commodity production in Zimbabwe has radically shifted, and so have the output markets. In Zimbabwe, grain crops and food staples account for over half of Zimbabwe's cultivated land area and overall agricultural output, and maize stands out as the most important grain crop, being both a staple food for the majority and a significant feed grain (Kapuya et al. 2010:10). It can be consumed as raw grain or processed into maize meal (Kapuya and Sihlobo 2014), as well as a variety of other food and industrial products including starch, sweeteners, oil, beverages, glue, industrial alcohol, and ethanol fuel (Ranum, Peña-Rosas, and Garcia-Casal 2014:105). There was a slowing down in maize production from the 1990s to 2002 (Pazvakavambwa 2009; Mudimu 2003), see Figure 3.1. The decline was as a result of the FTLRP (Mlambo 2005; Hammar and Raftopolous 2003). Thus, incessant droughts, the FTLRP-induced economic sanctions, and disruptions to farming operations resulted in a transitional decline in output over this period (Moyo et al. 2011; Scoones et al. 2010).

A decline in bank credit and shortages in farm inputs resulted in a drop in maize output from 2001 to 2004, according to Binswanger-Mkhize and Moyo (2012). Still, a shift from cash to food crops accounts for increases in maize output by resettled farmers, as was the case from 2005 (Figure 3.1). As Figure 3.1 shows, there was a further sustained decline in maize production between 2010 and 2016, which was reversed partly by the re-introduction of Command Agriculture by the government in 2016. Resettled farmers, who were responsible for the shift from cash to food crops,

Figure 3.1: Maize output, 1993-2017

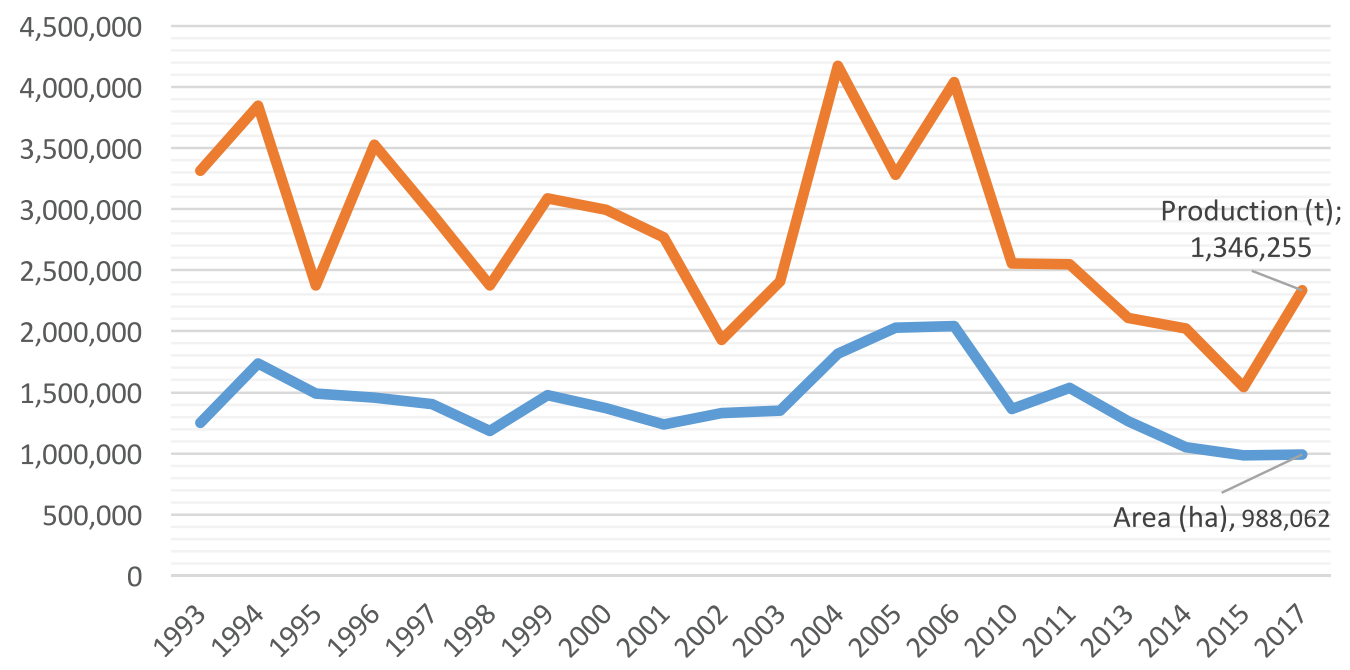

Source: Author's own, compiled using figures obtained from the Ministry of Agriculture, Mechanization and Irrigation Development database (2017) 
received support from the government's Command Agriculture, resulting in increased production.

The production of maize is highest in the wetter provinces in Mashonaland and Manicaland, located in the east and north-west of Zimbabwe, respectively. The reconfiguration of the agrarian structure, following the land reform, altered maize production patterns. Production shifted from LSCF production to SHFs resettled after 1980 and to the CAs that had begun producing maize during the colonial period. During the 1970s, about 5,000-6,000 LSCFs accounted for over 90 per cent of the maize delivered to the formal sector markets, and about 750,000 SHFs (in the Tribal Trust Lands) produced about 5 per cent. In comparison, about 8,000 SSCFs accounted for the remaining 5 per cent (Rohrbach 1989:2-3). During the early 1980s, resettlement increased the number of farmers and expanded the cultivated area in Zimbabwe. Between 1979 and 1985, cereal production in Zimbabwe increased by about 80 per cent, with maize production more than doubling. Fifty per cent of this increase in maize production was attributable to black smallholder production (Rohrbach 1989:2). A welfarist pro-peasant agricultural policy introduced by the new government of the ZANU PF resulted in a boom in maize production in the first decade after independence. The was accompanied by the opening up of more GMB depots to buy the crop from farmers, creating a ready and accessible market for maize.

As Figure 3.2 shows, CA farmers, alongside LSCFs and SSCFs, led the production of maize up until
2002. From 2004, SHFs accounted for the highest proportion of maize produced in Zimbabwe, in line with the tri-modal agrarian structure and government welfarist policies.

Thus, notwithstanding the fact that middle-scale farmers (A2) received the most support, they contributed less in maize output than SHFs (Shonhe 2018; Scoones et al. 2010), as deliveries to the GMB revealed. ${ }^{3}$

\subsection{Tobacco production}

Tobacco has been central to economic development and politics in Zimbabwe in the pre-and-post colonial period (Mbanga 1991). The national reconciliation policy introduced in 1980 led to a reversal of the drop in production associated with political uncertainties experienced at the time, as shown in Figure 3.3. The policy advocated for the non-adversarial co-existence of white colonisers and the black majority, which gave the white farmers confidence to continue investing in agriculture. Annual tobacco production was, therefore, on the rise and reached 237 million $\mathrm{kg}$ by 2000 (TIMB 2000). However, the land reform of 2000 eventually led to a drastic drop in annual tobacco production to 48 million kg by 2008 (TIMB 2018).

A new wave of rising tobacco production, driven by the newly resettled farmers, was experienced under the Government of National Unity (GNU) from 2009. The GNU liberalised agricultural commodity marketing and introduced the foreign currency retention policy for tobacco sales, which triggered a resurgence in

Figure 3.2: Maize output by sector, 1994-2017

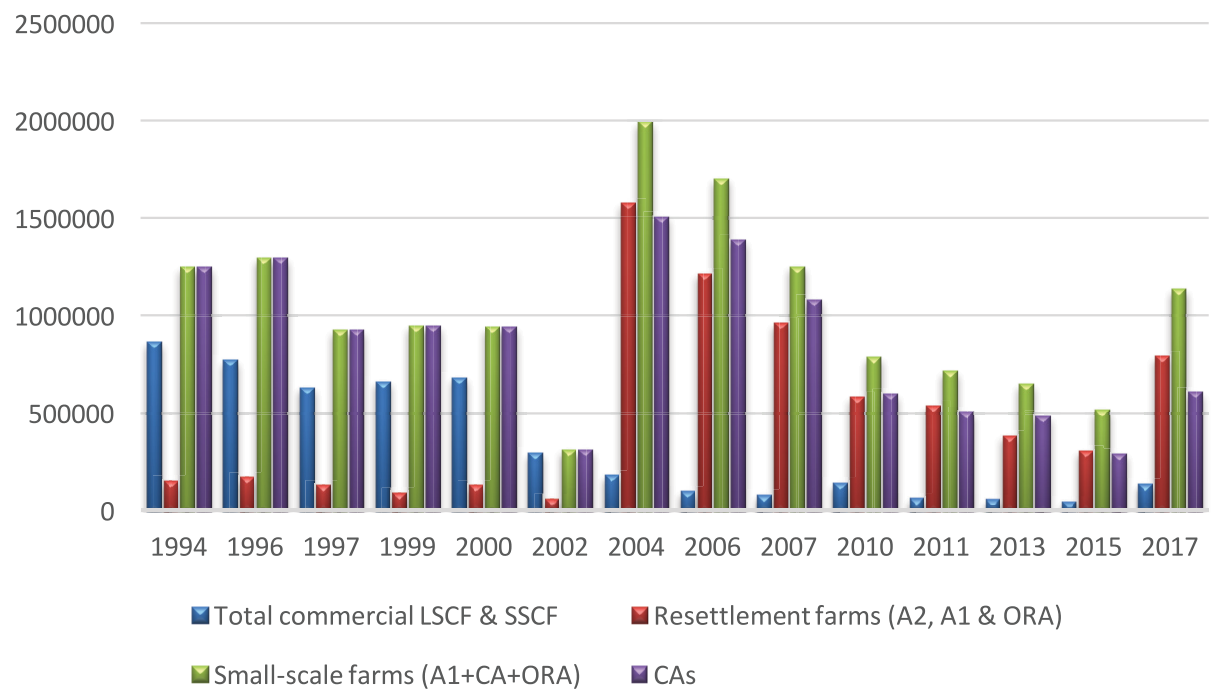

Notes: ORA refers to the old resettlement area

Source: Author's own, compiled using figures from the Ministry of Agriculture, Mechanization and Irrigation Development, Second Round Crop and Livestock Assessment (2017)

$3 \mathrm{KII}, \mathrm{PD}, 2020$ 
tobacco production and other commodities (Moyo et al. 2014; Binswanger-Mkhize and Moyo 2012). This new wave was characterised by the broader participation of farmers, dominated by smallholders in the CA and A1 sectors (Figure 3.4). Under the Look East policy developed in 2003, the China National Tobacco Corporation (CNTC) - a state-owned monopoly and the world's largest tobacco companies, Tian Ze Tobacco Company's (TZTC), subsidiary - oversaw the resurgence in contract farming and spurred growth in production from 2005 (Fang et al. 2020).

By 2020, 95.3 per cent of tobacco producers were growing under contract farming, supported by 36 tobacco merchants and delivering 95.5 per cent of total tobacco crop production (TIMB 2020). In this context, the production of a crop, which generates 24 per cent of the foreign currency in Zimbabwe, could now be produced by a broader mass of SHFs, who now accumulate from below. As a result, these sectors have increased their participation in the production of tobacco and its commodity circuit. For instance, LSCFs, which produced 94.5 per cent of tobacco in 2000, have been replaced by A1 farmers, who now contribute 27 per cent of total tobacco production. The CA farmers contribute 38 per cent, while A2 farmers contribute 27 per cent of total tobacco production, as shown in Table 3.1.

The SSCFs' contribution to total tobacco production rose to 8 per cent by 2017, after contributing next to nil in 2000. The land reform, therefore, shifted tobacco production from large-scale commercial farmers to small-scale commercial farmers. Access to tobacco

Figure 3.3: National tobacco output, 1975-2017

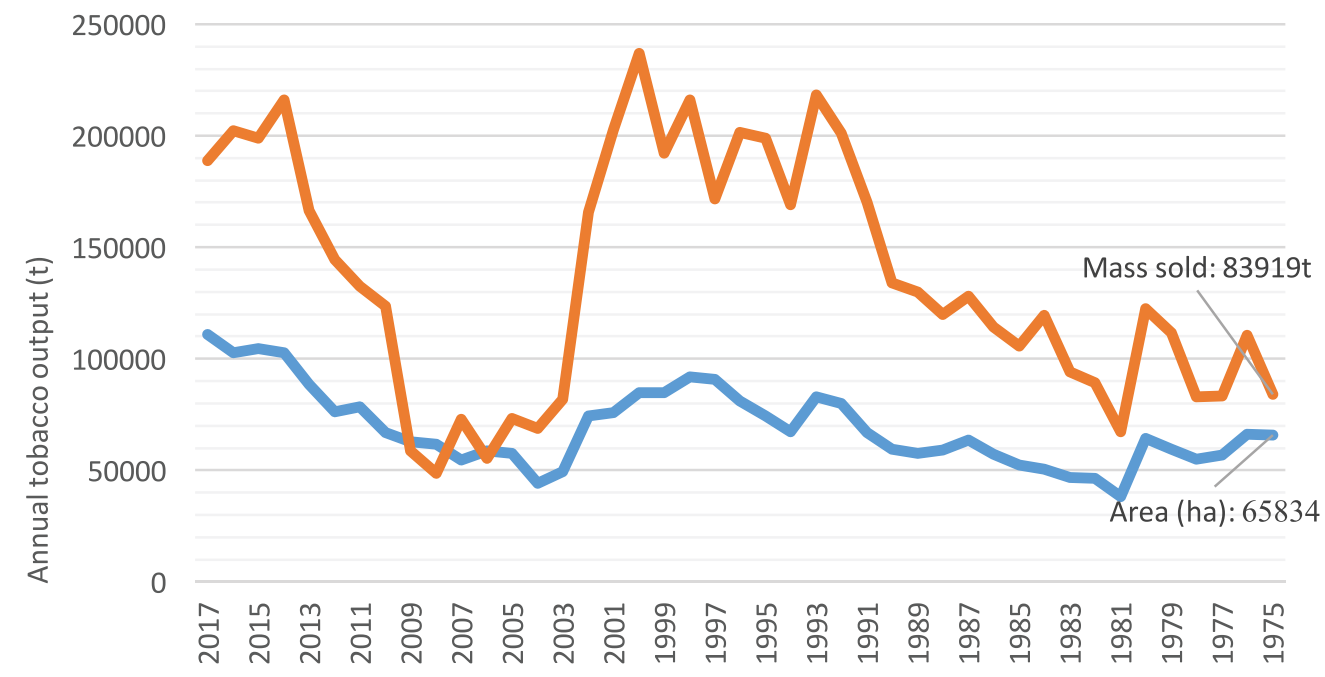

Source: Author's own, based on TIMB (2017)

Figure 3.4: Sectional tobacco output per sector, 1993-2017

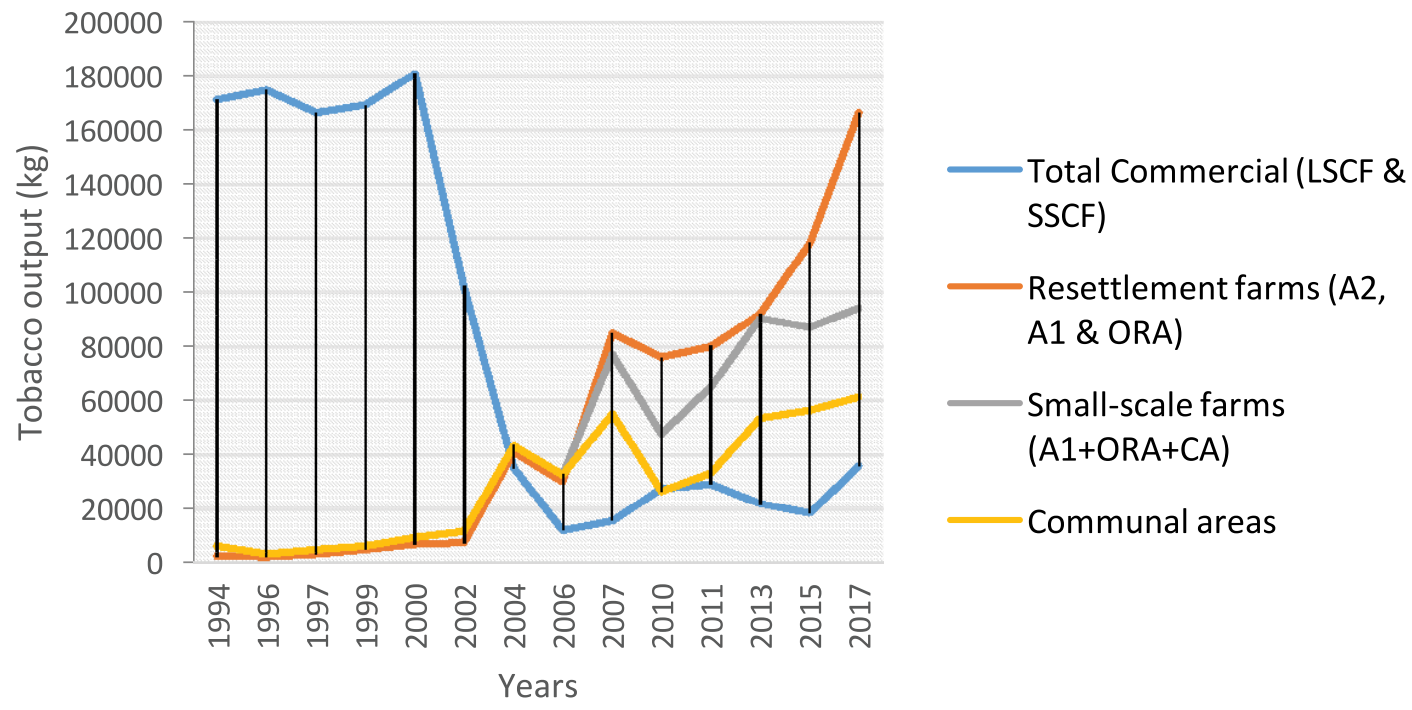

Source: Author's own, compiled using the Ministry of Agriculture, Mechanization and Irrigation Development, Second Round Crop and Livestock Assessment (2017) 
contract farming is broad, covering the $\mathrm{A} 1$ and $\mathrm{CA}$ farmers who have no bankable security. Tobacco growers are registered by the TIMB annually. Through this register, a stop order facility is used to manage growers' obligations to the state, as well as the contract farming system, where advanced amounts through banks or the contract farming system are deducted. Overall, the contract prices have been higher than those offered at the independent auction floors, such that some farmers who produce independently often sell under contract arrangements. Through the Tobacco Research Act (Chapter 28:21), the Tobacco Research Board (TRB) controls the production of tobacco seed and the regulation of chemicals used in the industry (Muroiwa, Mushunje and Musitini 2019; TRB 2017). These institutional arrangements have a bearing on the production and marketing of the two crops, as we discuss in the sections to follow.

Table 3.1: Week 53 mass deliveries by contract and non-contract farmers per farming model

\begin{tabular}{|l|l|l|l|l|l|l|l|}
\hline Type of funding & A1 & A2 & CAs & SSCFs & 2020 & 2019 & Variance \\
\hline Non-contracted $(\mathrm{kg})$ & $2,099,388$ & 514,042 & $3,316,481$ & 375,383 & $6,305,294$ & $21,489,282$ & -71 \\
\hline Contracted $(\mathrm{kg})$ & 36124709 & 37420323.6 & 48973944.89 & 10281614 & $132,800,591$ & $135,726,469$ & -2 \\
\hline Total crop (kg) & $38,224,097$ & $37,934,366$ & $52,290,426$ & $10,656,997$ & $139,105,885$ & $157,215,751$ & -12 \\
\hline $\begin{array}{l}\text { Percentage of 2020 } \\
\text { total (\%) }\end{array}$ & 27 & 27 & 38 & 8 & 100 & 8 & \\
\hline $\begin{array}{l}\text { Percentage of } \\
\text { contracted production } \\
\text { in 2020 (\%) }\end{array}$ & 95 & 99 & 94 & 96 & 95 & & \\
\hline
\end{tabular}

Source: Author's own, computed from TIMB (2020) 


\section{COMMODITY GIRCULATION: FROM MVURWI TO THE GLOBAL MARKETS}

Having discussed the changes in production patterns, to give context as to how the input and output markets are configured, this section turns to the rest of the commodity circuits, as elaborated in Figures 4.1 and 4.2.

\subsection{Maize input and output markets}

Figure 4.1 illustrates the maize commodity circuit. Given the limited financing options in post-FTLRP Zimbabwe (Moyo et al. 2014; Binswanger-Mkhize and Moyo 2012) farmers rely on the reinvestment of agrarian surplus (Shonhe 2019b), remittances (Scoones et al. 2010) and public contract farming - particularly Command Agriculture - and the Presidential Well Wishers Inputs Scheme. A2 farmers are mostly supported through the Command Agriculture programme as they are politically connected (Shonhe and Scoones unpublished). A2 farmers are comprised of bureaucrats and members of the military, who are also the gatekeepers of the programme, notwithstanding the logistical role played by the GMB. The presidential Well Wishers Input Scheme targets smallholders in the CAs and the A1 sector, providing maize crop inputs to farmers, sufficient only to meet subsistence production. Party leaders and traditional leaders work together in selecting beneficiaries. In most cases, those aligned to the ruling party tend to benefit, as state capacity is inadequate to support all farmers. Shonhe (2018) observed that the support increased during electoral periods, as was the case in 2005, 2008 and 2013.

However, the Command Agriculture programme and the Well Wishers Input Scheme do not provide sufficient inputs to the farmers as the demand is higher than the government supply. A female A2 farmeradvised:

We sell our maize crop to the GMB so that we get inputs the following [season], but the support is never adequate for our needs. We now resort to horticulture to generate funds to support our

Figure 4.1: Maize circuit

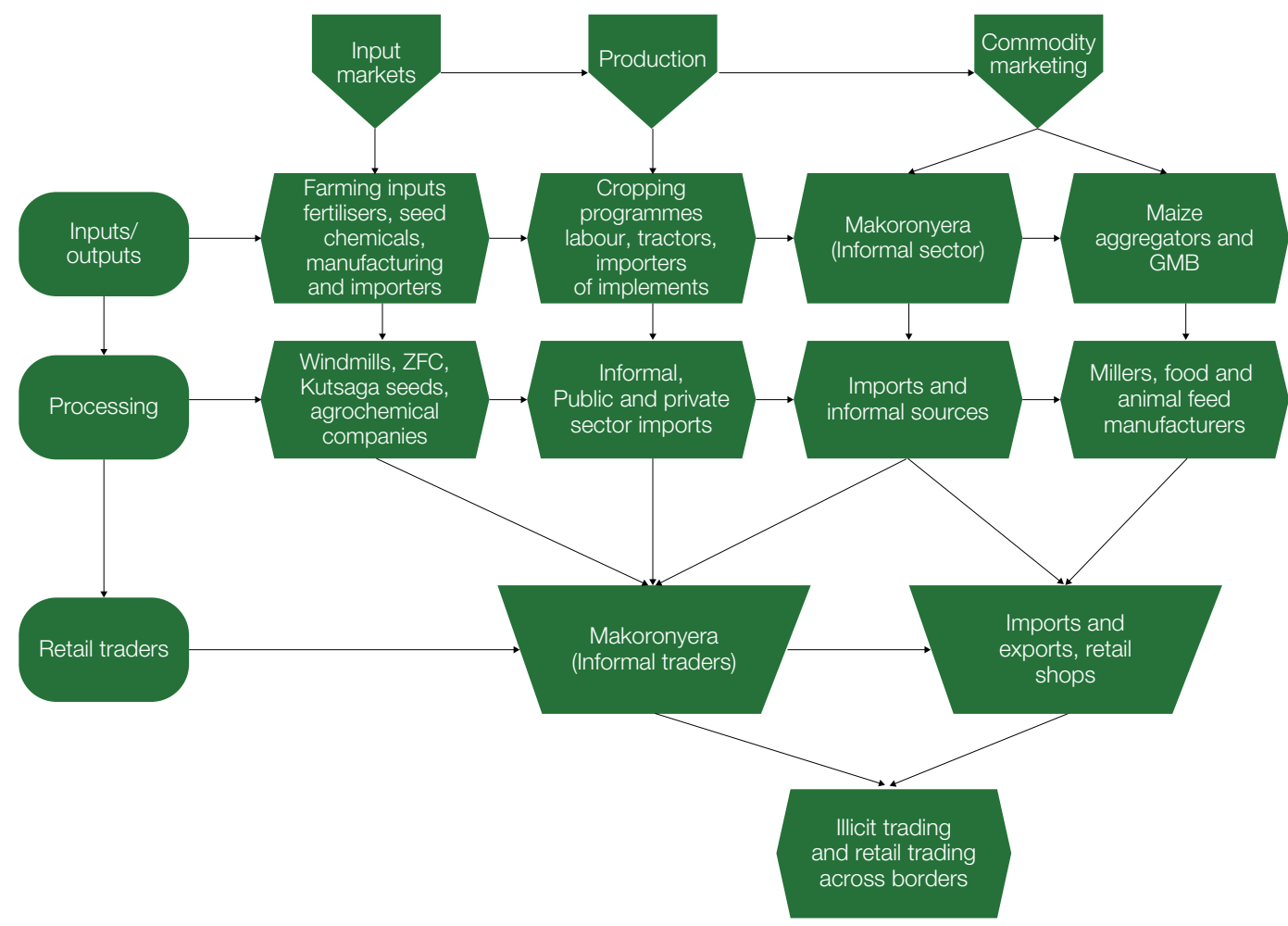

Source: Author's own 
maize and tobacco production and the rest of our farming. We also use the money to buy pipes and pumps for irrigation and to pay workers. ${ }^{4}$

Thus, while the sources of fertilisers, seed, and chemicals are aligned to the aforementioned financing arrangements, most farmers also access farming inputs from local agri-traders in the nearest towns, relying on their sales income to purchase these inputs (Shonhe 2017; Moyo et al. 2014). Unlike in the pre2000 period, where agricultural inputs were bought from big companies, small agri-traders now dominate in this area. ${ }^{5}$ Accompanying the FTLRP, changes were also experienced in the input supply chain, with the emergence of small traders who joined to compete with the big players. However, of the ten leading producers of seed maize, the most prominent are Seed Co Zimbabwe (a Zimbabwean company formed in 1983), Pannar (a South African company established in 1958), Agriseeds (Zimbabwean company), ARDA Seeds (state-owned by the Zimbabwean government), the Scientific and Industrial Research and Development Centre (locally-owned, established in 1986), and Pioneer Hi-Bred (an American company).

The purchase of seeds from South Africa is also typical across other commodities, including horticultural seeds. South African companies, such as Avanos and Charter seeds, are the main suppliers as they are perceived as cheaper. Besides, the use of retained and open-pollinated maize seed by Zimbabwean SHFs is increasing, owing to the high prices of marketed maize seed (Tibugari et al. 2019; World Bank 2015). The circuits for accessing fertiliser, chemicals, and farming machinery are similar to those identified for tobacco crop, illustrated in Figures 4.1 and 4.2.

The GMB is responsible for food security and has responsibility for buying and selling grain commodities in the country, controlling grain handling, storage, and processing facilities, and maintaining the national strategic grain reserve (Pazvakavambwa 2009). To this extent, the GMB currently enjoys a pervasive monopoly over the grain industry, even though this has intermittently shifted over time as state policy changes. For instance, between March and July 2020, monetary and exchange control regulations changed a record 12 times, affecting the pricing structure for tobacco and maize prices. The GMB buys a variety of crops from farmers and sells them to the domestic agro-processing industry. It also exports agricultural products to regional and international markets when there is excess supply, while importing agricultural commodities when they are in short supply locally.

The marketing of maize has reconfigured significantly since 2000, while maize processing has equally evolved. These changes were observed during the FGDs in Chiweshe, in Mvurwi: 'The markets for maize rapidly changes, along with government policies and demand from various buyers' ${ }^{6}$. For instance, the government often directed that all maize sales be carried out through the $\mathrm{GMB}$, as has been the case during periods and years of short supply, but informal sales also continued to take place. The GMB, which was previously only involved in buying and selling the grain, is now processing mealie meal through Silo, its subsidiary, formed after 2000. The makoronyera, dominant in tobacco marketing, are also common in maize marketing. They also include Mbare - Musika buyers in Harare. As such, 65.8 per cent of grain maize is sold through aggregators and traders/makoronyera, while 32.1 per cent is delivered to the GMB.

The GMB pays farmers in the local currency and there is often a delay in payment after delivery of the commodity to the depots. Farmers therefore tend to prefer selling to makoronyera because they promptly pay in US dollars. Farmers complain that the foreign exchange regime affects their bottom line, given the current distortions. For instance, an A1 farmer indicated that:

This year, 2020, the GMB is buying at $Z \$ 12,000$ and giving an incentive of 30 per cent for early delivery, increasing the price to $\mathbf{Z \$ 1 6 , 0 0 0}$ per t, which translates to US\$100 and US\$133 per $t$ respectively, the current informal exchange rate of US\$1:Z\$120. However, makoronyera are paying between US\$230 and US\$280 per t, making this a preferred market choice.

The 2020/21 producer price for maize was pegged at $Z \$ 32,000$ per $t$, which will likely cause distortions in the production of maize (Chulu 2020). While the price is an improvement from the previous seasons, there are concerns that it was announced late after farmers had already made concrete plans for the season. Moreover, these maize prices are well above the regional level, which may result in connected individuals getting involved in illegal exports at exorbitant margins. Chulu (2020: 12) observed that:

The maize guaranteed producer price is US\$400 per tonne at the forex auction rate or US\$320 per

4 Interview with Mrs DN, Mvurwi, 2 February 2020

5 Interview with A1 farmer, DK, in Mvurwi in March 2020

6 Interview with GV, Mvurwi, Hariana farm, 20 February 2020

7 ibid 
tonne at the unofficial exchange rate. In South Africa, the export parity price for maize is the equivalent of US\$150 per tonne. The world maize price is currently US\$155 per tonne. The world maize price is projected to rise to US\$160 per tonne. This means our guaranteed maize producer price is between 2.1-2.7 times the import parity price... With corruption rife, the producer price has likely created a honeypot for get-rich-quick schemes. History is likely to repeat itself.

While most maize was resold to households in urban areas, after 2000, an emerging market was the small grain millers, who bought directly from farmers and the GMB.. ${ }^{8}$ During 2020, the Grain Millers Association of Zimbabwe (GMAZ) was involved in the moderation of maize supply to millers. Due to inadequate supply from farmers in some years, the GMAZ was assigned the responsibility of importing maize into the country. ${ }^{9}$ This is a lucrative business as it involves enormous sums of money. ${ }^{10}$ The GMAZ has been accused of patronage and corruption in securing scarce foreign currency from the Reserve Bank of Zimbabwe (RBZ) and in the allocation of grain to millers (Chibamu 2020). There are also allegations that 'some millers were getting maize allocations from GMB beyond their plant capacities and would offload the excess on the black market' (Murwira and Muchedzi 2020), after being offered the commodity at subsidised prices. The actors given the licence to import maize and allocate grain to millers, including those given access to RBZ foreign currency allocations at this stage of the commodity circuits, is a matter of both political connections and patronage. There are fears that connected individuals will escalate this practice as maize prices are grossly distorted. These fears are worsened by emerging evidence revealing that despite existing shortages, maize is being exported to Zambia and the Democratic Republic of Congo through illegal means (Maverick Citizen 2021; Frykberg 2019).

The politics of the maize commodity circuit is linked to the financing of primary production and processing. Equally, the actors allocated the commodity for milling and eventually for retail trading is a political outcome (Poulton and Chinsinga 2018). In 2020, the GMB was selling to millers at subsidised prices, even though not all millers benefited. In Malawi, Chinsinga and Poulton (2014: 145) observed that the use of subsidies was 'plagued by elite capture and political manipulation' to gain and maintain political control and support (Banful
2011). In Zimbabwe, the military, which is involved in the Command Agriculture programme, and individuals with close connections to the ruling elites are observed to be benefiting from GMB subsidies. Those benefiting are either middle-scale farmers or elite in the GMAZ, who are connected to ruling ZANU-PF. The middlescale farmers and GMAZ hold sway in national policy making in various ways. For example, the middle-scale farmers control political support at the local level, which is mobilised for electoral victory during elections. The GMAZ controls rents through the distribution of grain to small grain millers, after importing or buying grain from the GMB, at concessionary prices.

\subsection{Tobacco input and output markets}

The input markets for tobacco production are intricately linked to the output marketing circuits under the funding arrangements, where contract farming and self-financing dominate. Contract farming refers to the 'relations between growers and private or state enterprises that substitute for open-market exchanges by linking nominally independent family farmers of widely variant assets with a central processing, export, or purchasing unit that regulates in advance price, production practices, product quality, and credit' (Watts 1994: 26-27).

Contracted farmers sell through merchant floors as prescribed in the contract agreement. Self-financed farmers can choose to sell through independent floors or merchant floors. Tobacco is predominantly grown under contract farming arrangements, with 94 per cent of CA farmers and 99 per cent of resettled farmers producing tobacco under such arrangements. As TIMB records show, at least 52.1 per cent of contracted tobacco is sold through aggregators and traders (makoronyera). Data collected from the farmers for this study shows that formal contract sales were far lower in 2020, at 30.3 per cent of total sales. This indicates the prevalence of illicit trade, which begins with makoronyera in the fields and at auction floors and is led by well-connected individuals involved in illegal cross border trade. Illicit trade is most prevalent between Zimbabwe, as the biggest tobacco producer in Africa, and its neighbouring countries, with South Africa being the most significant market. The ascendance of makoronyera - who offer to buy the crop at various stages (reaping, curing, grading, and marketing) - paying the full value in US dollars, has been on the rise since 2016. In the past, makoronyera have also been accused of manipulating the auction processes in collusion with buyers at the auction floors in Harare. A tobacco contractor observed that:

8 Interview with a grain miller, VR, in Harare, May 2020

9 Interview with GMAZ official, May 2020

10 For example, the Zimbabwean parliament carried out a public hearing to establish how GMAZ used US\$28.2 million allocated to it by the RBZ in 2017 (Chibamu 2020) 
Given the liquidity challenges in Zimbabwe, contract farming remains the only way to finance agriculture. We run a contract floor for the contracted farmers. We also have a structure of 50 extension officials with ten supervisors and four managers, who are mobile and available to assist the farmers. They use motorcycles and cars and can therefore quickly move from one farm to the other. We get off-shore loans from buyers who are overseas to finance buying of the tobacco leaf. The $R B Z$ provides operating loans. However, we face the challenge of side-marketing where farmers end up selling to other buyers who go to the farms, clandestinely. These end up selling the tobacco to other contractors to our disadvantage. ${ }^{11}$

Contracted farmers are provided with 'fertilisers, pesticides and herbicides, wage finance support and extension services',12 though this differs from company to company. In 2020, Zimbabwe had 36 tobacco merchants, seven of which were of foreign origin. These were Tian Ze from China; Zimbabwe Leaf Tobacco and Mashonaland Tobacco Company (MTC) from the US; Northern Tobacco (NT), which has local connections and links with the United Kingdom; Curverid Tobacco $P / L$ from Russia; and Intercontinental Leaf Tobacco Company and Premium Leaf Zimbabwe from the United Arab Emirates. In 2020, the top four companies (MTC, NT, Premium Leaf Zimbabwe, and Tian Ze) had bought
58.2 per cent of the contracted crop by day 53 of the marketing season. At the global level, Alliance One International and Universal Corporation control 40-60 per cent of the market. In fact, the top five multinational corporations control 80 per cent of the industry market (Goger, Bamber, and Gareffi 2014). Some of these companies have subsidiaries in Zimbabwe, for instance, Mashonaland Tobacco Company (Pvt.) Ltd is a subsidiary of Alliance One International. There are three independent tobacco auction floors - the Tobacco Sales Floor (TSF), Boka Tobacco Floor (BTF), and the Premier Tobacco Floor (PTF) - where tobacco grown by independent growers is marketed.

The two suppliers of tobacco seed are the Zimbabwe Tobacco Seed Association (ZTSA) (accounting for 31.2 per cent of the market) and Kutsaga, of the TRB (which makes up the remaining 68.8 per cent). In the fertiliser industry, Zimbabwe Fertilizer Company Pvt Ltd (ZFC) and Windmill lead in the supply of fertilisers to growers under independent and contract arrangements. However, much more fertiliser is imported from outside the country, mainly from South Africa, compared to the quantities used from local production. The chemical industry supply line is more comprehensive and so are the distribution channels. Cropserve, Superfert, Omnia, CP Chemicals, Windmill, Agricura, Bayer, and

Figure 4.2: Tobacco circuit

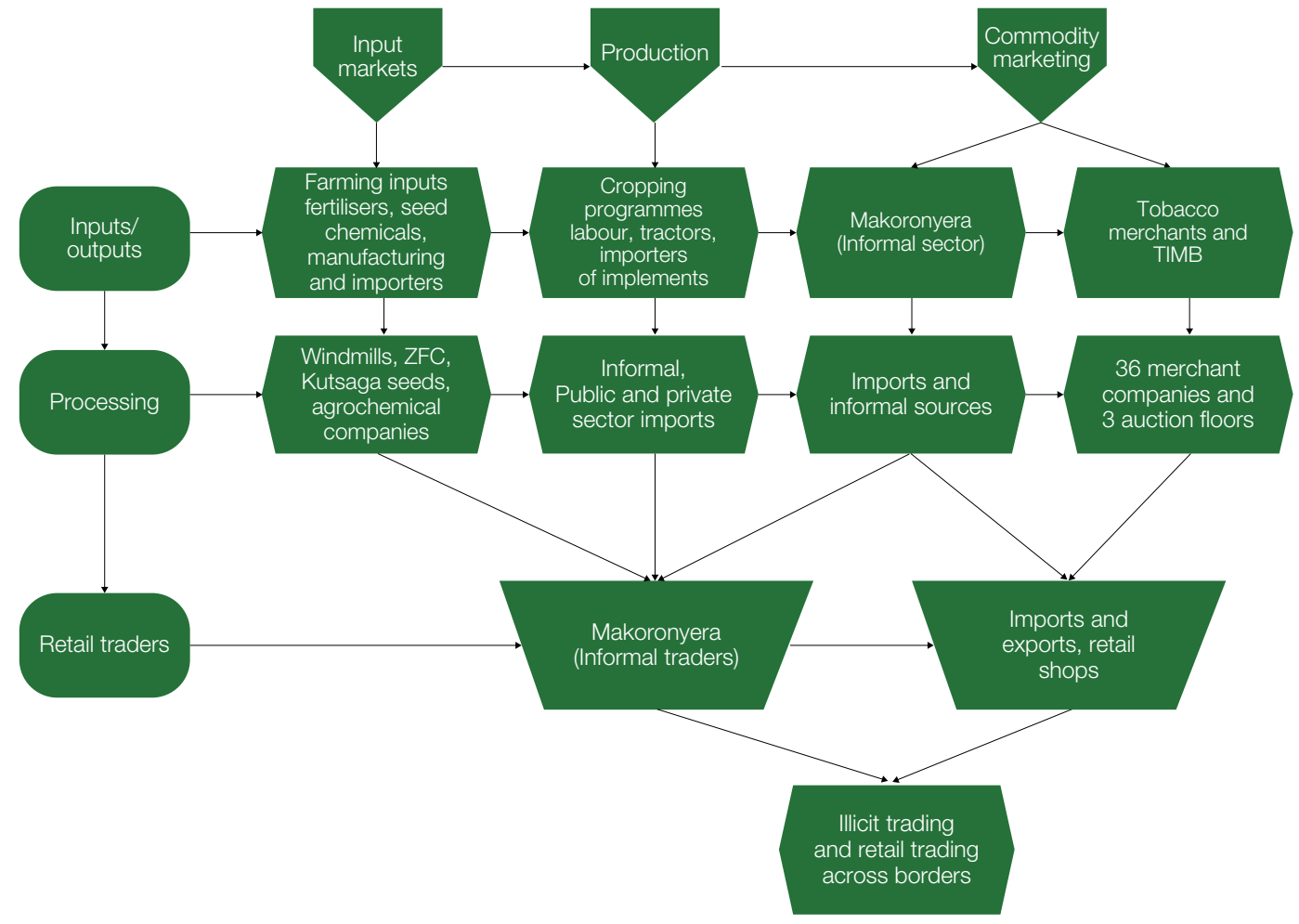

Source: Author's own

11 Interview with a tobacco contractor, SF, in Harare, June 2020

12 Interview with an A1 farmer, RP, in Mvurwi, February 2020 
ZFC are common in over 20 companies involved in fertiliser supply (TRB, 2020).

Over 98 per cent of tobacco crop is marketed in primary/semi-processed form, while the balance is used for the manufacturing of cigarettes and other tobacco products. China accounts for 47 per cent of Zimbabwe's tobacco exports, followed by Africa, mainly South Africa, (24 per cent) and the European Union (13 per cent). The Middle East accounts for 10 per cent of Zimabwe's tobacco exports, while the rest of Europe took the balance of 5 per cent in 2018. There are three tobacco processing companies in Zimbabwe. Tobacco Processors Zimbabwe processes 42 per cent of the tobacco processed in Zimbabwe and employs 1,800 seasonal workers, in addition to 148 permanent workers. The remaining 58 per cent is processed by Mashonaland Tobacco and Zimbabwe Leaf Tobacco.

There are also three major tobacco cigarette manufacturing companies in Zimbabwe, namely, British American Tobacco (BAT), Savanna Tobacco, and Gold Leaf, which sell mainly to South Africa (Hayson 2019). The other four manufacturers are BRECO, CUTREG Processors, The Cigarette Company, and Chelsea Tobacco (Nhorido 2013). Eighty per cent of manufactured cigarettes are exported. Due to the lucrative tobacco market in South Africa, based on the size of the population, 'Zimbabwe-produced cigarettes are smuggled into all its neighbouring countries, with the clear majority being smuggled into South Africa' (Hayson 2019: 4). 'Zimbabwe is reported to have lost billions of dollars through illegal trade. For example, South Africa is said to have lost R27 billion in tax revenue on the back of Zimbabwean tobacco illicit trade in the country between 2010 and 2016' (Nkala 2019). Illegal tobacco trade is also carried out in Botswana, Namibia, and Mozambique. In South Africa, as is the case for Zimbabwe, illicit tobacco trading has become central to political succession and interparty financing, it is therefore at the heart of power politics in both countries. Illicit tobacco trading involves some 'untouchables' in the highest levels in the governments of both Zimbabwe and South Africa (Hayson 2019), through patronage networks and campaign funding.

Thus, the illicit trade that begins with makoronyera in the farms and at auction floors leads to illegal cross border trading by 'untouchables' between Zimbabwe, as the biggest tobacco producer in Africa, and its neighbouring countries, particularly South Africa. The 'untouchables' have the support of the ruling elites. The tendency for politicians and policy makers to allow groups of elites to emerge and benefit from their protection is common (Poulton and Chinsinga 2018). A similar pattern was observed in the Rift Valley in
Kenya, where maize growers benefited, and in Mali and Burkina Faso, where cotton farmers took advantage of their political connections.

The informal marketing channels, which begin with makoronyera, lead to the illicit trade of tobacco through undesignated crossing points to Botswana, Mozambique, Namibia, and South Africa. Thus, the crop is diverted at the farmgate and either delivered to contracting companies, or exported directly through illegal channels. These illegal channels constitute the understated shadow economy, argued to be at 60.6 per cent of gross domestic product by the International Monetary Fund (Medina and Schneider 2018). BAT, which is involved in contract farming and the processing and manufacturing of tobacco and cigarettes, is reported to be leading the illicit tobacco trade into South Africa (Haydon 2019: 2). The Zimbabwe national economy and the farmers have lost enormous value due to this illicit trade, as this represents the perpetuation of primitive capital accumulation, where surplus value is extracted and exported to foster further development in developed countries. 


\section{CHANGING COMMODITY MARKETS UNDER COVID-19}

How has the COVID-19 pandemic reconfigured the tobacco and maize commodity circuits? The impact of COVID-19 on commodity circuits is evident in the input and output markets at national and local levels. The COVID-19 pandemic altered the maize and tobacco commodity circuits due to a combination of factors. COVID-19 regulations restricting farmers' movements exacerbated the informality of crop marketing during the 2020 marketing season, aiding surplus value expropriation through primitive accumulation. This has mainly resulted in SHFs losing income.

On 23 March 2020, the Zimbabwean government published laws which banned the gathering of more than 100 people, ordered the closure of borders and airports, and restricted movement except for identified critical services. In the commodity circuits, only the 'production supply, delivery or distribution of food (in particular supermarkets and food retail stores)' were permitted to operate under Statutory Instrument 83 of 2020. Disruptions to the transportation system and other logistics systems, including the closure of aggregation centres and warehouses, affected market access. The incidence of COVID-19 and the curtailment of movement imposed in response to the virus, resulted in the decline in daily deliveries of tobacco by independent farmers in 2020 (TIMB 2020).

\subsection{Changes in Maize marketing patterns under COVID-19}

In terms of maize marketing, Table 5.1 shows that under COVID-19 restrictions, local makoronyera were able to buy more maize at lower prices due to the lower prices offered by the GMB and the inability of outside buyers to travel to these areas to purchase maize. As a result, informal maize prices dropped from as high as US\$7 per 20kg (bucket) to US\$3 per bucket, when comparing the same period for 2019 and 2020. GMB maize deliveries have remained uninterrupted. ${ }^{13}$ Due to an acute maize shortage emanating from the low maize production in the previous season, the government opted to ensure that the GMB remained open to take maize deliveries from farmers. Most of the crop was grown under the Command Agriculture facility and it was therefore in the government's interest to ensure deliveries were made before side-marketing could take place. Besides, it was also in the interests of policy makers, many of whom are involved in maize production, as they constitute the majority of the $\mathrm{A} 2$ farmers.

Maize trading in the informal sector also remained high as vulnerable growers facing cash shortages under the weight of COVID-19 were forced to sell at far lower prices and to fewer local makoronyera. Despite the GMB introducing incentives for early delivery, by March/ April of 2020, the public entity had collected 600t. This quantity of maize deliveries was similar to the 2019 season, which was a drought year. ${ }^{14}$ While the GMB has been able to maintain deliveries to state approved processors, the informal sector has been hampered by travel restrictions, such that local buyers have not been able to transport the crop to areas outside Mazowe. This has exacerbated hunger challenges in Harare and other urban centres.

\subsection{Changes in tobacco marketing patterns under COVID-19}

Due to Covid-19, the start of the tobacco marketing period shifted from 20 March (the start date in 2019) to 29 April 2020 (Chikwati 2020; Chikwati and Chasokela 2019), thereby affecting revenue streams for farmers and other stakeholders along the commodity circuits. When the auction floors were opened, a litany of regulations were imposed. These changes resulted in farmers facing many challenges. For example, during an FGD, ${ }^{15}$ farmers in Mvurwi complained that they were facing the following challenges in marketing their tobacco crop:

- Some contract companies, which did not have direct contact with foreign buyers, ended up inviting other buyers to their auction floors. This results in lower prices to accommodate the fee payable to the contracting company. In such cases, farmers 
receive low prices and might lose out, especially if they are not present during the auction.

- The use of a complex matrix in calculating the pricing leads to buyers manipulating the prices as farmers are not familiar with the system.

- $\quad$ The mixing of tobacco leaves of poor quality with good quality tobacco to lower the price. This is common where farmers are not present during the auction process.

- Disqualifying whole tobacco bales on the basis of only a few poor quality leaves that can be removed. This results in the need to regrade the tobacco and causes unnecessary additional costs or may result in an unexplained loss of weight.

- $\quad$ Transporters are also accused of making changes to tobacco bales during transportation.

- Delayed payments due to the use of incorrect details, which farmers are unable to immediately correct as they are not present during the sale.

- Farmers lack information as the representatives sent to the sale are not trained to deal with the emerging information. Besides, the representatives are only given five minutes to assess the sale after the process has been concluded. This timeframe is inadequate for an effective assessment to be carried out.

- Stop orders are also being placed for farmers' without their consent. This results in deductions being made upon the sale of tobacco without the farmers' knowledge.

- $\quad$ Some tobacco bales are getting lost and farmers are losing value due to their inability to effect timely follow-ups.

- Deliberate exchange of price tags, which results in farmers being paid a lower value for the crop.

Summarising these changes and the impact thereof, a CA farmer ${ }^{16}$ underscored:

The travel restrictions imposed by the government because of Covid-19 stipulated that farmers with less than 100 bales of tobacco are not allowed on the auctioning floors. For us, as small farmers, we have to select one farmer to coordinate transportation and the logistics of selling at the auction floors. This practice is a disadvantage as farmers tend to lose influence over the price as they can neither negotiate nor withhold their bales. In the end, this will affect their revenue and thus our ability to reinvest in farm inputs declines.

Table 5.1: Changes in commodity delivery/sales, 2019 and 2020

\begin{tabular}{|c|c|c|c|c|c|c|}
\hline \multirow{2}{*}{$\begin{array}{l}\text { Type of } \\
\text { produce } \\
\text { sourced }\end{array}$} & \multirow{2}{*}{$\begin{array}{l}\text { Frequency } \\
\text { of supply }\end{array}$} & \multirow{2}{*}{$\begin{array}{l}\text { Amount } \\
\text { sourced before } \\
\text { lockdown/ } \\
\text { COVID-19 (kg } \\
\text { or another } \\
\text { measure) (2019) }\end{array}$} & \multirow{2}{*}{$\begin{array}{l}\text { Amount } \\
\text { sourced } \\
\text { post lockdown } \\
\text { / COVID-19 } \\
\text { (kg or another } \\
\text { measure) (2020) }\end{array}$} & \multicolumn{2}{|c|}{ Price of produce } & \multirow[t]{2}{*}{ Comment } \\
\hline & & & & $\begin{array}{l}\text { Before } \\
\text { COVID-19 } \\
\text { lockdown } \\
\text { (2019) in } \\
\text { US\$/kg }\end{array}$ & 2020 & \\
\hline \multicolumn{7}{|c|}{ Tobacco: contractors } \\
\hline \multirow[t]{2}{*}{ C } & Weekly & 200 bales & 40 bales & \multirow{2}{*}{$1.60-4.50$} & \multirow{2}{*}{$2.30-5.0$} & $\begin{array}{l}\text { The price is not } \\
\text { constant. }\end{array}$ \\
\hline & Monthly & 800 bales & 160 bales & & & $\begin{array}{l}\text { - Logistical challenges } \\
\text { and mistrust led to a }\end{array}$ \\
\hline \multirow[t]{2}{*}{$\mathrm{D}$} & Weekly & $14000 \mathrm{~kg}$ & $7000 \mathrm{~kg}$ & \multirow[b]{2}{*}{2.80} & \multirow[b]{2}{*}{3.50} & \\
\hline & Monthly & $56000 \mathrm{~kg}$ & $28000 \mathrm{~kg}$ & & & $\begin{array}{l}\text { makoronyera at the } \\
\text { auction floors led to } \\
\text { reduced corruption and } \\
\text { improved prices. }\end{array}$ \\
\hline \multicolumn{7}{|c|}{ Maize: makoronyera } \\
\hline \multirow[t]{2}{*}{ E } & Weekly & $2 \mathrm{t}$ & $5 t$ & \multirow[t]{2}{*}{$7.0 / 20 \mathrm{~kg}$} & \multirow[t]{2}{*}{$3.0 / 20 \mathrm{~kg}$} & \multirow{4}{*}{$\begin{array}{l}\text { - Increases in local } \\
\text { purchases because } \\
\text { other makoronyera } \\
\text { from other places are } \\
\text { not able to move freely. } \\
\text { - However, prices have } \\
\text { dropped due to limited } \\
\text { competition. }\end{array}$} \\
\hline & Monthly & $8 \mathrm{t}$ & $20 t$ & & & \\
\hline \multirow[t]{2}{*}{ F } & Weekly & $1 \mathrm{t}$ & $5 t$ & \multirow{2}{*}{$5.0 / 20 \mathrm{~kg}$} & \multirow{2}{*}{$3.0 / 20 \mathrm{~kg}$} & \\
\hline & Monthly & $4 \mathrm{t}$ & $20 t$ & & & \\
\hline
\end{tabular}

Source: Author's own, APRA and CASA Study, 2020

16 Interview with an independent farmer, GB, July 2020 
There were also further delays in the delivery of tobacco as some farmers avoided delivering their crop in anticipation that the COVID-19 travel restrictions would be relaxed sooner and enable them to attend the auction process. ${ }^{17}$ Deliveries were at 50 per cent of previous levels in week 53 of the 2020 marketing season, and they were hardly expected to reach 75 per cent of anticipated levels by the end of the tobacco selling season (Table 5.1).

Some farmers suggest the decentralisation ${ }^{18}$ of the marketing system to smaller towns, where auction floors were established, made it difficult for companies to manipulate prices and for tobacco makoronyera in Harare to collude with buyers to manipulate the prices. $^{19}$ It is, however, argued that some companies passed the cost of the decentralised auction system on to the farmers. Despite this, the limited corruption ultimately led to better prices for farmers. ${ }^{20}$

\subsection{The supply of productive assets under COVID-19}

The supply of goods from South Africa was also disrupted, even though formal agri-trading remained open across the borders. Initially, the supply was interrupted by the total closure of business in South Africa. However, this was later relaxed. ${ }^{21}$ By the time this relaxation took place, cross border procurement of goods was already facilitated illegally through undesignated points (Scoones 2020) akin to those used in illicit tobacco cigarette trading. This illegal route attracts higher operational costs due to rent-seeking and the bribes paid to security officers. Ultimately, these costs are passed on to the farmers and the consumers. As a result, the quantity of products sold by agri-traders was quartered between 2019 and 2020, while selling prices increased by 50 per cent for productive assets and herbicides (Table 5.2).

The impact of these changes in supply prices are likely to be more evident during the next cropping season, as crop income changes begin to reflect a shift in input prices/supply and to impact on production processes. This delayed impact will likely be significant, as farmers tend to rely on the reinvestment of farm income rather than financing from other sources (Scoones 2020; Shonhe 2019b; Moyo et al. 2014). For example, a decline in income would likely lead to decreased reinvestment in the cropping programme for the next season. The changes resulting from COVID-19 also include shortages of labour and closure of markets due to the limits to movement under COVID-19 restrictions. In some cases, contract farmers have been required to recruit state police and nurses at their own cost, which has increased their operational costs, eating into their profit margins. So, precisely who wins and who loses along the commodity circuits and to what effect? The next section assesses the social differentiation and social difference, in the shifting context of the GCCs.

Table 5.2: Changes in agro-trading under COVID-19

\begin{tabular}{|c|c|c|c|c|c|c|c|}
\hline $\begin{array}{l}\text { Agri - } \\
\text { trader }\end{array}$ & Commodity & Frequency & $\begin{array}{l}\text { Quantities } \\
\text { sold (2019) }\end{array}$ & $\begin{array}{l}\text { Quantities } \\
\text { sold under } \\
\text { COVID-19 } \\
\text { restrictions } \\
\text { (2020) }\end{array}$ & $\begin{array}{l}\text { Prices in } \\
\text { US\$ per } \\
\text { item (2019) }\end{array}$ & $\begin{array}{l}\text { Prices in } \\
\text { US\$ per } \\
\text { item under } \\
\text { COVID-19 } \\
\text { restrictions } \\
(2020)\end{array}$ & Comment \\
\hline \multirow[t]{4}{*}{$A$} & \multirow{2}{*}{$\begin{array}{l}\text { Water } \\
\text { pumps }\end{array}$} & Weekly & 4 & 1 & \multirow{2}{*}{120} & \multirow{2}{*}{180} & \multirow{8}{*}{$\begin{array}{l}\text { Runners } \\
\text { delivering } \\
\text { goods from } \\
\text { South Africa } \\
\text { charge a } 30 \\
\text { per cent fee, } \\
\text { resulting in } \\
\text { price hikes }\end{array}$} \\
\hline & & Monthly & 16 & 4 & & & \\
\hline & \multirow{2}{*}{$\begin{array}{l}\text { Solar panels } \\
(100 w)\end{array}$} & Weekly & 5 & 1 & \multirow{2}{*}{55} & \multirow{2}{*}{80} & \\
\hline & & Monthly & 20 & 4 & & & \\
\hline \multirow[t]{4}{*}{$B$} & Herbicides & Weekly & 4001 & 1001 & \multirow{2}{*}{ US\$6/I } & \multirow{2}{*}{ US\$9/I } & \\
\hline & & Monthly & 16001 & 4001 & & & \\
\hline & Fertilisers & Weekly & $1000 \mathrm{~kg}$ & $400 \mathrm{~kg}$ & \multirow{2}{*}{ US\$25/50kg } & \multirow{2}{*}{ US\$29/50kg } & \\
\hline & & Monthly & $4000 \mathrm{~kg}$ & $1600 \mathrm{~kg}$ & & & \\
\hline
\end{tabular}

Source: Author's own, APRA and CASA Study, 2020

17 Interview tobacco contracting company official, VS, July 2020

18 Decentralised auction systems entailed the setting up of auction floors in smaller towns in tobacco farming areas, such as Mvurwi, by contracting companies. The cost to set up a facility includes rental fees for space, additional labour costs, accommodation for the employees, and so on. The contracting companies are accused of pushing these costs on to the farmers through the manipulation of the pricing matrix.

19 Interview with Mrs DN, Mvurwi, 2 February 2020

20 Interview with Mrs DN, Mvurwi, 2 February 2020

21 Interview with agri-trader in Mvurwi, June 2020 


\section{POLITICS AND SOCIAL DIFFERENTIATION: WHO WINS AND LOSES?}

In Mvurwi, access to land, agrarian finance, and markets is differentiated across gender and class. Differences and contestations over access to resources are fluid and depend on dynamic social relations, which produce social differentiation (Dancer and Hossain 2018; Berry 1993). This social differentiation is often deepened by commoditisation and economic liberalisation, which cause inequality and the exclusion of some social groups (Dancer and Hossain 2018; Hall, Scoones and Tsikata 2017). Politics and patronage connections also lead to social differentiation as rents are distributed unequally. This is noticeable along the commodity circuits for maize and tobacco, as in-depth interviews have revealed. Through inequality in the use of unpaid care work, carried out mostly by women, social difference is also noticeable.

\subsection{Gender relations}

Access to Command Agriculture financing and private contract farming facilities is differentiated by gender, across the farming sectors. As Table 6.1 shows, 25 per cent of A2 women farmers participate in Command Agriculture, producing maize, while none have access to contract farming. In the A1 model, however, 20.7 per cent of women farmers are involved in private tobacco contract farming. In this model, tobacco contracting companies limit financing of tobacco production to 1ha per person, as such, households tend to secure additional support by getting the wives to enter into a separate contract farming agreement.

In the A2 model, where no such limitations exist, women have no access to contract farming. At least 15.8 per cent of women in the CA have direct access to private contract farming. Unlike private contract farming, access to Command Agriculture is mediated by political patronage, as women occupy less influential positions, they tend to be excluded, unless they access the programme through their husbands. Instead, women are more involved in unpaid care work and domestic chores, including preparing food for casual and permanent farm workers for no pay. Women often have no involvement in key decision making, their inability to secure assets reflects unequal power dynamics associated with patriarchal tendencies. As intersectional theorists have observed, these tendencies reflect how exploitative and oppressive structures (Dancer and Hossain 2018), including the GCCs remain unfavourable to female farmers. As a result of differences in access to land and finance, as well as the unequal ability to mobilise labour, which is highly significant for tobacco production, women's independent participation in maize and tobacco production is low.

Table 6.2 shows that none of the $\mathrm{A} 2$ female farmers produced a tobacco crop of their own. The cropped area for tobacco and maize was also lower among the female $\mathrm{A} 1$ and CA farmers. A2 female farmers had a cropped area of 15ha, compared to 25.4ha among the male farmers, for maize and tobacco crops. This trend was also observed among the CA farmers, though the margin was lower.

A difference was also observed in the income earned by male and female farmers. Across the three farming models, female farmers earned less than their male counterparts. Even though female A1 farmers had an equal area of cropped land to male A1 farmers, their earnings were US\$2,532.90, compared to US $\$ 4,389.30$ for male farmers. Again, this translated to skewed asset accumulation, as Table 6.3 shows. Except in the A1 model, where male and female farmers have an average of 1.1 ox-ploughs and 0.5 tractors, male farmers own more farming assets and houses

Table 6.1: The percentage of women farmers accessing financing and marketing through the different farming models

\begin{tabular}{|l|l|l|}
\hline Model & Command Agriculture (\%) & Contract farming (\%) \\
\hline A2 & 25.0 & 0 \\
\hline A1 & 0 & 20.7 \\
\hline CA & 2.4 & 15.8 \\
\hline
\end{tabular}

Source: Author's own, APRA survey, 2018-19

Sample: Mvurwi NA1=310; NCA $=520 ; N A 2=40$ 
than their female counterparts. Importantly, none of the female farmers across the farming models own generators. Generators are used to support irrigated crops and enable farmers to engage in horticulture, as well as year-round cropping programmes, enhancing their revenue earning potential. As such, the failure to access generators implies that women are not able to carry out irrigated cropping programmes of their own.

\subsection{Generational and class differences}

The level of youth involvement in the value chains was also analysed through the assessment of their access to Command Agriculture and contract farming. In terms of the tri-modal agrarian structure (Moyo 2011), the CA and A1 models represent the poor peasantry, while the A2 model is made up of middle-scale and large-scale farmers (rich capitalists).

Access to Command Agriculture and contract farming finance was higher among A2 farmers, compared to the other models/classes. For example, across all ages, access to Command Agriculture finance was high among A2 farmers (47.5 per cent), compared to A1 farmers (16.1 per cent) and CA farmers (2.7 per cent). Similarly, among the youth, 43.6 per cent of A2 farmers had access to Command Agriculture finance, compared to 16.0 per cent and 5.0 per cent for $A 1$ and CA farmers, respectively. The same trend is observed in contract farming, where the financing and marketing of tobacco is involved.

The COVID-19 induced disruptions to the commodity circuits, experienced in the food-based and tobacco commercialisation pathways, will worsen inequity in income, capital accumulation, and social differentiation across farming sectors. Moreover, as women are the least entrusted to accompany bales to market floors by tobacco farmers, they tend to suffer more losses as the process is more prone to manipulation. For example, farmers complain of lost bales, delayed payment, and low prices. Some emerging farmer associations have been campaigning for better prices and full payment in foreign currency, as well as for increased government

Table 6.2: Crop production by gender per farming model

\begin{tabular}{|l|l|l|l|l|l|}
\hline \multirow{2}{*}{ Sector } & Gender & $\begin{array}{l}\text { Cropped area } \\
\text { (ha) }\end{array}$ & $\begin{array}{l}\text { Maize cropped } \\
\text { area (ha) }\end{array}$ & $\begin{array}{l}\text { Tobacco } \\
\text { cropped area } \\
\text { (ha) }\end{array}$ & $\begin{array}{l}\text { Total crop } \\
\text { income (US\$) }\end{array}$ \\
\hline \multirow{3}{*}{ A2 } & Male & 25.4 & 13.4 & 2.1 & 104101.4 \\
\cline { 2 - 6 } & Female & 15.0 & 11.5 & 0 & 96970.0 \\
\cline { 2 - 6 } & Grand total & 24.3 & 13.2 & 1.9 & 103388.3 \\
\hline \multirow{3}{*}{ A1 } & Male & 5.0 & 1.7 & 0.9 & 4389.3 \\
\cline { 2 - 6 } & Female & 5.0 & 1.6 & 0.7 & 2532.9 \\
\cline { 2 - 6 } & Grand total & 5.0 & 1.7 & 0.8 & 4019.0 \\
\hline \multirow{2}{*}{ CA } & Male & 2.3 & 18.8 & 0.5 & 963.3 \\
\cline { 2 - 6 } & Female & 1.8 & 0.5 & 0.4 & 372.4 \\
\cline { 2 - 6 } & Grand total & 2.1 & 12.8 & 0.5 & 823.4 \\
\hline
\end{tabular}

Source: Author's own, APRA survey, 2018

Sample: Mvurwi NA1=310; NCA=520; NA2=40

Table 6.3: Average asset ownership by gender per farming model

\begin{tabular}{|l|l|l|l|l|l|l|l|}
\hline Sector & Gender & Ox-plough & $\begin{array}{l}\text { Scotch- } \\
\text { cart }\end{array}$ & Tractors & Vehicles & Generators & $\begin{array}{l}\text { Brick under } \\
\text { asbestos } \\
\text { houses }\end{array}$ \\
\hline \multirow{2}{*}{ A2 } & Male & 1.1 & 0.6 & 0.9 & 0.6 & 0.5 & 1.0 \\
\cline { 2 - 8 } & Female & 0.8 & 0.5 & 0.5 & 0.3 & 0 & 0.5 \\
\cline { 2 - 8 } & Grand total & 1.1 & 0.6 & 0.9 & 0.6 & 0.5 & 1.0 \\
\hline \multirow{2}{*}{ A1 } & Male & 1.1 & 0.9 & 0.5 & 0.2 & 0.1 & 0.6 \\
\cline { 2 - 8 } & Female & 1.1 & 0.8 & 0.5 & 0.1 & 0 & 0.7 \\
\cline { 2 - 8 } & Grand total & 1.1 & 0.9 & 0.5 & 0.2 & 0.1 & 0.6 \\
\hline \multirow{2}{*}{ CA } & Male & 0.8 & 0.6 & 0.1 & 0.2 & 0.1 & 0.9 \\
\cline { 2 - 8 } & Female & .07 & 0.4 & 0.0 & 0.1 & 0.0 & 0.9 \\
\cline { 2 - 8 } & Grand total & 0.8 & 0.5 & 0.0 & 0.2 & 0.1 & 0.9 \\
\hline
\end{tabular}

Source: Author's own, APRA survey, 2018

Sample: Mvurwi NA1=310; NCA=520; NA2=40 
support. However, success has been slow, as their voices remain unheard. ${ }^{22}$ Thus, patterns of capital accumulation and social differentiation, evident along the commodity circuits, are derived from differentiated access to land and financing opportunities, which are tied to broad macro-economic policies and the politics of commodity circuits.

\subsection{Labour relations}

Another critical input is labour, with tobacco considered a labour intensive crop (Goger, Bamber, and Gareffi 2014: 9), a fact which makes tobacco farming an essential source of employment (Shonhe 2019b). Consequently, labour is an essential consideration amongst inputs for the production of the crop. Sakata (2015) notes that under the contract farming arrangement, some contracting companies do support the farmer with money for labour while others do not. There is also a distinction in terms of the use of labour between different farm settlement models. The medium-scale and large commercial or capitalist farms rely almost exclusively on hired labour (Moyo 2013), while smallholder production is largely organised around family labour (Chambati 2013). Due to weak farmworker associations, most workers, especially women, are employed on a casual basis.

As mentioned, in the SHF class, there is a tendency to rely on family labour, which leads to the conversion of farmers into disguised workers, working for global capital (see Shonhe 2017), as was observed in Mvurwi. Within the context of a failing economy, where farmers lack the capacity to meet labour costs, farmworkers often have to wait for the marketing of the crop, and thus share the risks of failing weather patterns and challenges with the farmers. This is a difficult arrangement for workers, who live from hand to mouth but are expected to defer their social reproduction needs.

\subsection{Entangled accumulation, political settlement, and social difference}

In all, the commodity circuits for maize and tobacco are tied to their financing models. Due to liquidity challenges in Zimbabwe, there are two primary financing models relied upon by farmers - Command Agriculture and private contract farming for maize and tobacco, respectively. However, there is a growing informalisation of the marketing channels - makoronyera - which undermines the contracting arrangements, but also attracts higher rewards for farmers in both circuits. COVID-19 has disrupted the production and circulation of agricultural commodities, affecting the pricing structure in the input and output markets. While prices improved for the tobacco crop compared to the 2019 farming season, primitive capital accumulation (Shonhe 2018; Shivji 2008) continues to undermine overall farmer accumulation, though differently, across farming models.

In the food-based commercialisation pathway, COVID-19 instigated changes have undermined farmer accumulation as prices have been depressed due to limited demand, since makoronyeras are unable to move freely to engage in farmgate purchases. While the GMB has introduced an early maize delivery incentive and relaxed moisture content requirements, prices remain low and unfavourable to farmers. Thus,

Figure 6.1: Financing options for youth in Mvurwi area for 2016/17 season
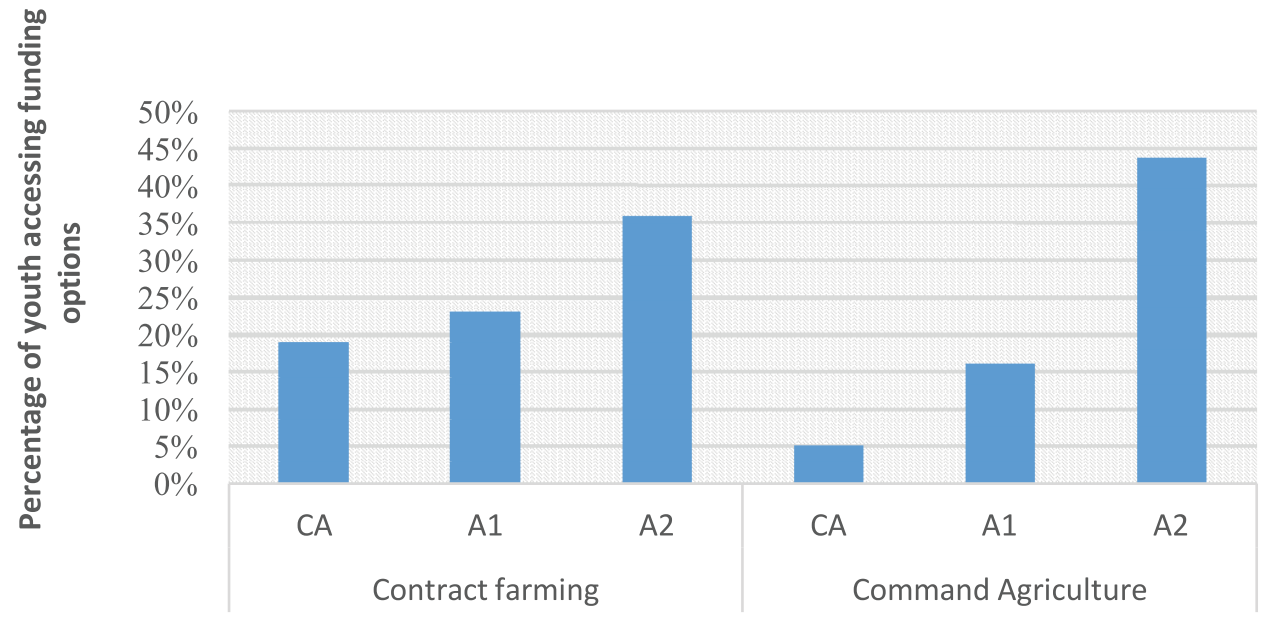

Farming models

Sample: Mvurwi NA1=310; NCA $=520 ; N A 2=40$

Source: Author's own, APRA study, 2017-21

22 Interview with GMB official in Harare, 6 July 2020 
even though public procurement remains available, the prices are unstable and unviable. Through pillaging, associated with unfair pricing and illicit trading, entangled accumulation subsists across commercialisation pathways and along the GCCs for maize and tobacco crops. Overall, maize farmers are immensely affected by COVID-19, while makoronyera have benefited from the shifts in commodity circuits.

Tobacco farmers also experienced losses in income under the weight of COVID-19 regulations, despite the decentralisation of tobacco marketing. Farmers argue that tobacco merchants are manipulating purchasing prices to maximise their profits and cover the increased administration costs. Tobacco growers are less confident of the new marketing system as they were not allowed to participate at the auction floors, as was the case in previous years. In spite of this informalisation, the politics of commodity circuits and patronage remain essential for A2 farmers, who are accumulating from above, and less critical for A1 farmers, predominantly involved in accumulating from below.

\subsection{Collapsing state regulations}

\section{and the militarisation of agricultural financing}

The illicit trade in maize and tobacco undermines agricultural commercialisation, with growers, whose voices are weak and fragmented, as the biggest losers amidst poor state regulation and monitoring. In contrast, the powerful GMAZ and the Zimbabwe Association of Tobacco Merchants command extensive policy influence. The general collapse of state regulatory systems has resulted in the input and output markets for both crops being characterised by illegal cross border trade, which is currently on the rise. This informal makoronyera circuit undermines contract farming arrangements and is a result of unfavourable state policies over time. It is also reflective of the more general state failure to enforce law and order across sectors, which has generated a growing sense of impunity in society.

The makoronyera are part of the shadow economy, which accounts for over 60.6 per cent of business in Zimbabwe. In the input markets, the commodity circuits are partially militarised as the security forces administering Command Agriculture wield excessive control, despite ongoing efforts towards privatisation. In essence, this militarisation has effectively replaced state institutions charged with enforcing policy and regulations. At the processing level, the GMAZ benefits from its proximity to political elites and the political power in the ruling party. This is synonymous with trends in other sectors, such as artisanal mining, where connected individuals also dominate. In essence, the increasing level of impunity, related to the overall collapse of government infrastructure, enables the flourishing of the makoronyera and state militarisation, which are now pervasive in all segments of the commodity circuits in Zimbabwe.

\subsection{Entangled accumulation and the social relations of production}

Global capitalism ensures that primitive accumulation is inherently embedded in agricultural GCCs. Contract farming arrangements are the new form of export financing, which exploit cheap labour and cheap raw materials in the periphery. Whether it is through the export of tobacco or the import of maize, illicit and unfair pricing - entangled accumulation - has been worsened by the incidence of COVID-19 and the restriction imposed in response to the pandemic. Patriarchal relations ensure that women are excluded from Command Agriculture and that only through circumventing the limitations of capitalism are women openly encouraged to access contract farming within farming households. Within the context of global capitalism, where primitive accumulation is the primary driver of expansion into the periphery and the social relations of production are influenced by patriarchal attitudes towards women, inequality and the exclusion of vulnerable groups is enhanced. Besides, the primacy of politics in Africa's agricultural commercialisation pathways means that women who inherently occupy far lower positions of influence always come second best. 


\section{CONCLUSION}

This paper established that informal trading is a new normal, although it makes agricultural planning difficult and undermines farmer accumulation as it annihilates agribusiness confidence, and with it, prospects for furthering agricultural commercialisation. The introduction of new technologies, the decentralisation of tobacco marketing, and the reintroduction of producer prices for maize from the 2020/21 agricultural season provide scope for undercutting the role of makoronyera. However, this might also expand the scope for increased accumulation by farmers. The government's responsibility in eradicating impunity for corruption and providing an enabling macro-economic environment for sustainable commodity circuits cannot be over-emphasised. However, in the absence of a coherent voice from growers', labour, and womens' associations, it is the buyers and millers who have control over commodity markets, including illicit makoronyera trade, across border trading. The precarious conditions of growers, labour, women, and the youth is made worse by COVID-19, as the regulations imposed constrain their ability to accumulate. 
Banful, A.B. (2011) 'Do Formula-based Intergovernmental Transfer Mechanisms Eliminate Politically Motivated Targeting? Evidence from Ghana', Journal of Development Economics 96.2: 380-390

Bellemare, M.F. (2015) 'Contract Farming: What's in it for Smallholder Farmers in Developing Countries?', Choices 30.3: $1-4$

Berry, S.S. (1993) No Condition is Permanent: The Social Dynamics of Agrarian Change in Sub-Saharan Africa, Madison: University of Wisconsin Press

Binswanger-Mkhize, H. and Moyo, S. (2012) Zimbabwe from Economic Rebound to Sustained Growth: Note Il: Recovery and Growth of Zimbabwe Agriculture, Harare: World Bank

Chambati, W. (2013) 'The Political Economy of Agrarian Labour Relations in Zimbabwe After Redistributive Land Reform', Agrarian South: Journal of Political Economy 2.2: 189-211

Chibamu, A. (2020) 'Musarara Used Personal Funds to Import Wheat and Avert Zim Bread Shortages', New Zimbabwe, 24 May (accessed 4 August 2020)

Chikwati., E. (2020) 'Tobacco Fetches US\$4/kg on Opening Day', The Herald, 30 April, (accessed 27 July 2020)

Chikwati., E and Chasokela., E. (2019) '2019 Tobacco Marketing Season off to Slow Start' The Herald, 21 March (accessed 27 July 2020)

Chinsinga, B., and Poulton, C. (2014) 'Beyond Technocratic Debates: The Significance and Transience of Political Incentives in the Malawi Farm Input Subsidy Programme (FISP)', Development Policy Review 32.2: 123-150

Chitongo, L. (2017) The Efficacy of Small Holder Tobacco Farmers on Rural Development in Zimbabwe, Doctoral dissertation, University of the Free State (Qwaqwa Campus)

Chulu, B. (2020) 'Farming Frankenstein Monster and Not-so-smart Smart Farming', The NewsHawks, 4 December (accessed 18 March 2021)

Cousins, B. and Scoones, I. (2010) 'Contested Paradigms of 'Viability' in Redistributive Land Reform: Perspectives from Southern Africa', The Journal of Peasant Studies 37.1: 31-66

Dancer, H. and Hossain, N. (2018) Social Difference and Women's Empowerment in the Context of The Commercialisation of African Agriculture APRA Working Paper 8, Brighton: Future Agricultures Consortium

De Janvry, A. (1981) The Agrarian Question and Reformism in Latin America, Baltimore: Johns Hopkins University Press

Fang, J.; De Souza, L.; Smith, J. and Lee, K. (2020) '“All Weather Friends": How China Transformed Zimbabwe's Tobacco Sector' International Journal of Environmental Research and Public Health 17.3: 723

Frykberg, M. (2019) 'Reports of Zimbabwe-Zambia Standoff Over Illegal Maize Sales', African News Agency, 1 July (accessed 18 March 2021)

Fontes, V. (2017) 'David Harvey: Dispossession or Expropriation? Does Capital Have an "Outside"?' Revista Direito e Praxis 8.3: 2199-211

Grant, W.; Wolfaardt, A. and Louw, A. (2012) Technical Report: Maize Value Chain in the SADC Region, Gaborone: United States Agency for International Development (USAID) Southern Africa 
Gereffi, G. (2005) 'The Global Economy: Organization, Governance, and Development', The Handbook of Economic Sociology 2:160-182

Gereffi, G. and Fernandez-Stark, K. (2011) Global Value Chain Analysis: A Primer, Durham: Center on Globalization, Governance \& Competitiveness (CGGC), Duke University

Gereffi, G.; Humphrey, J. and Sturgeon, T. (2005) 'The Governance of Global Value Chains’, Review of International Political Economy 12.1: 78-104

Goger, A.; Bamber, P. and Gereffi, G. (2014) The Tobacco Global Value Chain in Low-income Countries, Durham: Center on Globalization, Governance \& Competitiveness, Duke University

Gonçalves, G.L. and Costa, S. (2020) 'From Primitive Accumulation to Entangled Accumulation: Decentring Marxist Theory of Capitalist Expansion', European Journal of Social Theory 23.2: 146-164

Gono. G. (2020) 'Gideon Gono: The Truth About RBZ Debt and Farm Mechanization', The Herald, 19 July (accessed 18 March 2021)

Government of Zimbabwe (2020) Public Health (COVID-19 Prevention, Containment and Treatment) (National Lockdown) Order, 2020, Supplement to the Zimbabwean Government Gazette Extraordinary Dated 28 March 2020, Harare: Government Printers

Hall, R.; Scoones, I. and Tsikata, D. (2017) 'Plantations, Outgrowers and Commercial Farming in Africa: Agricultural Commercialisation and Implications for Agrarian Change', The Journal of Peasant Studies 44.3: 515-537

Hammar, A. and Raftopoulos, B. (2003) 'Zimbabwe's Unfinished Business: Rethinking Land, State and Nation', in A. Hammar and B. Raftopoulos (eds.), Zimbabwe's Unfinished Business: Rethinking Land, State and Nation in the Context of Crisis, Harare: Weaver Press

Hayson, S. (2019) The Illicit Tobacco Trade in Zimbabwe and South Africa: Impacts and Solutions, Washington: Scowcroft Centre for Strategy and Security, Atlantic Council of the United States (accessed 18 March 2021)

IFPRI (2020) Impacts of the COVID-19 Crisis on Vegetable Value Chains in Ethiopia, Washington: International Food Policy Research Institute (IFPRI), Washington (accessed 18 March 2021)

Kapuya, T. and Sihlobo, W. (2014) South Africa's Maize Exports: A Strategic Export Market Analysis Model Approach, unpublished paper (accessed 16 March 2021)

Kapuya, T. et al. (2010) The Grain Industry Value Chain in Zimbabwe, unpublished report prepared for the Food and Agricultural Organization of the United Nations, Harare

Leandro, M. and Schneider, F. (2018) Shadow Economies Around the World: What Did We Learn Over the Last 20 Years, IMF Working Paper 18/17, Washington: International Monetary Fund (IMF)

Luxemburg, R. (2015) The Accumulation of Capital, Abingdon-on-Thames: Routledge

Mango, N. et al. (2018) 'Maize Value Chain Analysis: A Case of Smallholder Maize Production and Marketing in Selected Areas of Malawi and Mozambique', Cogent Business \& Management 5.1: 1503220-150

Maverick Citizen (2021) Report on Cartel Power Dynamics in Zimbabwe, Maverick Citizen (accessed 18 March 2021)

Mazwi, F.; Chambati, W. and Mudimu, G.T. (2020) 'Tobacco Contract Farming in Zimbabwe: Power Dynamics, Accumulation Trajectories, Land Use Patterns and Livelihoods', Journal of Contemporary African Studies 38.1: $55-71$

Mazwi, F.; Chambati, W. and Mutodi, K. (2018) Contract Farming Arrangement and Poor- resourced Farmers in Zimbabwe, Harare: SMAIAS Publications

Mazwi, F.; Chemura, A.; Mudimu, G.T. and Chambati, W. (2019) 'Political Economy of Command Agriculture in Zimbabwe: A State-led Contract Farming Model', Agrarian South: Journal of Political Economy 8.1-2: 232-257 
Mbanga, T. (1991) Tobacco, A Century of Gold. ZIL Publications (Pvt) Ltd

Medina, L. and Schneider, F. (2018) Shadow Economies Around the World: What Did We Learn Over the Last 20 Years? (No. 18/17), Washington: International Monetary Fund

MAMID (2017) Second Round Crop and Livestock Assessment, Harare: Ministry of Agriculture, Mechanization and Irrigation Development (MAMID)

MLAWCRR (2017) Second Annual Crop Assessment Report, Harare, Ministry of Lands, Agriculture, Water, Climate and Rural Resettlement (MLAWCRR)

Mlambo, A.S. (2005) 'Land Grab' or 'Taking Back Stolen Land': The Fast Track Land Reform Process in Zimbabwe in Historical Perspective', History Compass 3.150: 1-21

Moyo, S. (2011) 'Changing Agrarian Relations After Redistributive Land Reform in Zimbabwe', Journal of Peasant Studies 38.5: 939-966

Moyo, S.; Chambati, W.S; Mazwi F. and Muchetu, R.G. (2014) Land Use, Agricultural Production and Food Security Survey: Trends and Tendencies, 2013/14 African Experiencies, Harare: Sam Moyo African Institute for Agrarian Studies

Moyo, S. and Nyoni, N. (2013) Changing Agrarian Relations after Redistributive Land Reform. Land and Agrarian Reform in Zimbabwe: Beyond White Settler Capital, Dakar: Council for the Development of Social Science Research in Africa (CODESRIA) and African Institute for Agrarian Studies (AIAS)

Moyo, S. (2013) 'Land reforms and redistribution in Zimbabwe Since 1980', in S. Moyo and W. Chambati (eds.) Land and Agrarian Reform in Zimbabwe: Beyond White-Settler Capitalism, Dakar: Council for the Development of Social Science Research in Africa (CODESRIA)

Murisa, T. and Chikweche, T. (eds.) (2015) Beyond the Crises: Zimbabwe's Prospects for Transformation, Harare: Weaver Press

Muroiwa, J.; Mushunje, A. and Musitini, T. (2019) 'The Institutional and Socio-Economic Constraints to Smallholder Tobacco Production and Marketing in Mount Darwin District of Zimbabwe: The Value Chain Approach', Journal of Economics and Sustainable Development 10.7: 85-101

Murwira, Z. and Muchedzi, R. (2020) 'Maize Scam Sucks in GMB Executives', The Herald, 19 February (accessed 4 August 2020)

Mutyasira, V. and Sukume, C. (2020) Agricultural Commercialisation Pathways, Input Use, and Crop Productivity: Evidence from Smallholder Farmers in Zimbabwe, APRA Working Paper 28, Brighton: Future Agricultures Consortium (accessed 3 August 2020)

Nkala, I. (2019) Tobacco Farming in Zimbabwe: Profit, Problems and Solutions, Agriorbit, 31 December (accessed 3 August 2020)

Nhorido, E.P. (2013) A Value Chain Analysis of Flue Cured Virginia Leaf Tobacco in Zimbabwe, Master's thesis). University of Zimbabwe

Ochieng, J.; Knerr, B.; Owuor, G. and Ouma, E. (2016) 'Commercialization of Food Crops and Farm Productivity: Evidence from Smallholders in Central Africa', Agrekon 55.4: 458-82

Otañez, M.G.; Muggli, M.E.; Hurt, R.D. and Glantz, S.A. (2006) 'Eliminating Child Labour in Malawi: A British American Tobacco Corporate Responsibility Project to Sidestep Tobacco Labour Exploitation', Tobacco Control 15.3: $224-230$

Pauw, J. (2017) The President's Keepers: Those Keeping Zuma in Power and Out of Prison, Cape Town: Tafelberg

Pazvakavambwa, S. (2009) 'Zimbabwe: Achieving Household and National Food Security' excerpted from the paper, Achieving Household and National Food Security in Zimbabwe, prepared under the A-MDTF initiative. Washington: World Bank (accessed 26 March 2020) 
Poulton, C. and Chinsinga, B. (2018) The Political Economy of Agricultural Commercialisation in Africa, APRA Working Paper 16, Brighton: Future Agricultures (accessed 26 March 2020)

Ranum, P.; Peña-Rosas, J.P. and Garcia-Casal, M.N. (2014) 'Global Maize Production, Utilization, and Consumption', Annals of the New York Academy of Sciences 1312.1: 105-112

Rohrbach, D.D. (1989) The Economics of Smallholder Maize Production in Zimbabwe: Implications for Food Security, Michigan: Michigan State University

Rubert, S. C. (1998) A Most Promising Weed: A History of Tobacco Farming and Labor in Colonial Zimbabwe, 1890-1945 (Vol. 69), Athens: Ohio University Press

Sakata, Y. (2015) International Companies and Contract Farmers After Fast Track Land Reform Programme in Zimbabwe, Harare: Sam Moto African Institute of Agrarian Studies

Scoones, I. (2015) 'Zimbabwe's Land Reform: New Political Dynamics in the Countryside', Review of African Political Economy 42.144: 190-205

Scoones, I. et al. (2010) Zimbabwe's Land Reform: Myths \& Realities, Oxford: James Currey

Scoones, l.; Mavedzenge, B.; Murimbarimba, F. and Sukume, C. (2018) 'Tobacco, Contract Farming, and Agrarian Change in Zimbabwe', Journal of Agrarian Change 18.1: 22-42

Scoones, I. (2020) 'COVID-19 Lockdown in Zimbabwe: 'We are Good at Surviving, but Things are Really Tough': Reflections on Recent Conversations with Colleagues in Zimbabwe', Social Science in Humanitarian Action Platform, 17 June (accessed 18 March 2021)

Shonhe, T. (2017) Reconfigured Agrarian Relations in Zimbabwe, Bamenda: Langaa RPCIG

Shonhe, T. (2018) The Political Economy of Agricultural Commercialisation in Zimbabwe, APRA Working Paper 12, Brighton: Future Agricultures Consortium

Shonhe, T. (2019a) Tractors and Agrarian Transformation in Zimbabwe: Insights from Mvurwi, APRA Working Paper 21, Brighton: Future Agricultures Consortium

Shonhe, T. (2019b) 'The Agrarian Question in Contemporary Zimbabwe', Africanus 49.1: 1-24

Shonhe, T. (2020) 'Primitive Accumulation and Mugabe's Extroverted Economy: What Now Under the Second Republic?', in S.J. Ndlovu-Gatsheni and P. Ruhanya (eds.) The History and Political Transition of Zimbabwe, New York: Palgrave Macmillan

Shonhe, T. (unpublished) 'The Enduring IFFs and Erosion of the Golden Leaf Potential in Southern Africa' in a forthcoming book edited by Djouou Kamga Serges

Shonhe, T. and Mtapuri, O. (2020) 'Zimbabwe's Emerging Farmer Classification Model: A 'New' Countryside', Review of African Political Economy 47.165: 363-381

Shonhe, T. and Scoones, I. (unpublished) 'Private and State-led Contract Farming in Zimbabwe: Social Differentiation, Class Formation and Rural Politics', Journal of Agrarian Change

Sibanda, E. and Khumalo, P. (2017) 'Local Resources and Strategies for Orphan Care in Rural Communities: Perspectives of the Affected People in a Southern District of Zimbabwe', Gender \& Behaviour 15.3: 9483-9501

Shivji, I.G. (2008) Accumulation in an African Periphery: A Theoretical Framework, Dar es Salaam: Mkuki na Nyota Publishers

Tibugari, H. et al. (2019) 'Poor Maize Productivity in Zimbabwe: Can Collusion in Pricing by Seed Houses be the Cause?', Cogent Food \& Agriculture 5.1: 1682-230

The Economist (2020) 'Suddenly, Hope: The Promise of the New Covid-19 Vaccine is Immense', The Economist, 12 November, (accessed 18 March 2021) 
TIMB (2015) Contribution of Tobacco to GDP and Total Exports, Harare: Tobacco Industry and Marketing Board (TIMB)

TIMB (2018) Tobacco Industry and Marketing Board Annual Statistical Report. Harare: Tobacco Industry and Marketing Board (TIMB)

TIMB (2000) Tobacco Industry and Marketing Board Annual Statistical Report. Harare: Tobacco Industry and Marketing Board (TIMB)

TIMB (2020) 'Tobacco Weekly Report 29', Tobacco Industry and Marketing Board, 17 July, (accessed 24 July 2020)

TRB (2017) 'About Us', Tobacco Research Board (accessed 10 March 2020)

TRB (2020) Agrochemicals Approved by the Tobacco Research Board, 27 April, Harare: Tobacco Research Board (TRB (accessed 24 July 2020)

van der Ploeg, J.D. (2020) 'From Biomedical to Politico-economic Crisis: The Food System in Times of Covid-19', The Journal of Peasant Studies 47.5: 944-972

Van Loggerenberg, J. (2019) Tobacco Wars, Cape Town: Tafelberg

Wallerstein, I. (1974) 'Dependence in an Interdependent World: The Limited Possibilities of Transformation Within the Capitalist World Economy', African Studies Review 17.1: 1-26

Watts, M.J. (1994) 'Life Under Contract: Contract Farming, Agrarian Restructuring, and Flexible Accumulation', in P.D. Little and M. Watts (eds.), Living Under Contract: Contract Farming and Agrarian Transformation in SubSaharan Africa, Madison: University of Wisconsin Press

World Bank (2015) Agricultural Sector Assessment Study, Final Report, Zimbabwe Multi Donor Trust Fund, Washington DC: World Bank

Zinn, M.B. and Dill, B.T. (1996) ‘Theorizing Difference from Multiracial Feminism', Feminist Studies 22.2: 321-31 


\section{APPENDIX}

\section{Interviews and focus group discussions}

Interview with Mrs DN, Mvurwi, Hariana farm 21 February 2020

Interview with a grain miller, VR, in Harare, May 2020

Interview with GV, Mvurwi, Hariana farm, 20 February 2020

Interview with a tobacco contractor, SF, in Harare, June 2020

Interview with an A1 farmer, RP, in Mvurwi, February 2020

Interview with GMB official in Harare, 6 July 2020

Interview with an independent farmer, GB, July 2020

Interview with tobacco contracting company official, VS, July 2020

Interview with agri-trader in Mvurwi, June 2020

FGD at Madhidhidhi farm, 2 March 2020 
Shonhe, T. (2021) COVID-19 and the Political Economy of Tobacco and Maize Commodity Circuits: Makoronyera, the 'Connected' and Agrarian Accumulation in Zimbabwe, APRA Working Paper 55, Brighton: Future Agricultures Consortium Toendepi Shonhe

(c) APRA 2021

ISBN: 978-1-78118-790-6

DOI: 10.19088/APRA.2021.009

\section{(cc) BY-NC-ND}

This is an Open Access report distributed under the terms of the Attribution-Non Commercial-No Derivs 4.0 Unported (CC BY-NC-ND 4.0) Attribution - You must give appropriate credit, provide a link to the license, and indicate if changes were made. You may do so in any reasonable manner, but not in any way that suggests the licensor endorses you or your use. NonCommercial — You may not use the material for commercial purposes. NoDerivatives - If you remix, transform, or build upon the material, you may not distribute the modified material. You are free to: Share - copy and redistribute the material in any medium or format.

https://creativecommons.org/licenses/by-nc-nd/4.0/legalcode

If you use the work, we ask that you reference the APRA website (www.future-agricultures.org/apra/) and send a copy of the work or a link to its use online to the following address for our archive: APRA, Future Agricultures Consortium, University of Sussex, Brighton BN1 9RE, UK (apra@ids.ac.uk)

All APRA Working Papers go through a review process before publication. DO YOU HAVE COMMENTS ON THIS PAPER?

\section{@creative}

We would welcome your feedback on this working paper!

To provide brief comments, please follow this link to our short APRA Working Paper Feedback form: https://goo.gl/forms/1iVnXhhrIGesfR9

Agricultural Policy Research in Africa (APRA) is a programme of the Future Agricultures Consortium (FAC) which is

generating new evidence and policy-relevant insights on more inclusive pathways to agricultural commercialisation in sub-Saharan Africa. APRA is funded with UK aid from the UK Foreign, Commonwealth \&

Development Office (FCDO) and will run from 2016-2022.

The APRA Directorate is based at the Institute of Development Studies (IDS), UK (www.ids.ac.uk), with regional hubs at the Centre for African Bio-Entrepreneurship (CABE), Kenya, the Institute for Poverty, Land and Agrarian Studies (PLAAS), South Africa, and the University of Ghana, Legon. It builds on more than a decade of research and policy engagement work by the Future Agricultures Consortium (www.future-agricultures.org) and involves more than 100 researchers and communications professionals in Africa, UK, Sweden and USA. 